\title{
Selefi Din Anlayışlarının Psiko-Sosyal Olumsuz Yansımaları
}

\author{
Mustafa Sarmış \\ Dr. Öğr. Üyesi, Aksaray Üniversitesi (ROR ID: 026db3d50) \\ İslami İlimler Fakültesi, Din Sosyolojisi Anabilim Dalı \\ Assist. Prof. Dr., Aksaray University, Faculty of Islamic Education \\ Department of Sociology of Religion, Aksaray/Turkey \\ mustafa.sarmis@hotmail.com \\ ORCID: 0000-0003-0363-4861
}

\section{Psycho-Social Negative Reflections of Salafi Understandings of Religion Abstract}

The main claim of this article is that Salafi religious understandings lead to many negative psychological and sociological (psycho-social) consequences. At the same time, these elements are not only related to Salafism and Salafi groups, but also they are generally related to the belief elements of most Muslim individuals and groups. In this context the purpose of article is to reveal the mutually affected psycho-social negative features that have emerged in the past and present and may also come to light in the future, even though there are many different features that characterize Salafi thought. In the article, research and evaluation are made through an interdisciplinary method. In this framework, basic informations and discussion topics that will provide comprehension of Salafi understandings of religion of different disciplines are discussed in relation to the research areas of the Sociology of Religion. Firstly, the characteristics and basic attitudes of Salafi religious conceptions that may have negative psycho-social consequences are described, afterwards these attitudes are listed separately and the negative effects they can cause are explained within successive effect framework by presenting cause-and-effect relationship. As a result of the research, it has been seen that the characteristics of Salafi understandings of religion that may have negative consequences are as follows: 1-Disregard of the socio-cultural anthropological approach 2-A constant understanding of faith and religion at the basic level 3Apparent/literal approach 4-Unity in faith and actions 5-The thought that reason cannot comprehend religious issues 6-The idea that the Qur'an is not created 7-Constructing daily life through religious texts 8-Being limited to the Golden Age 9-The blessing of the language 10-Standing against history and tradition 11-Looking for the solutions to post/modern problems through past 12-Opposition to bid'ah (innovation) 13-The only truth discourse 14Absolutisation of religious knowledge 15-Standing against cultural construction 16Sanctifying religious authorities 17-Mission of tabligh (reaching out) 18-'Ummah understanding 19-Dār Al-Harb (abode of war) discourse 20-Patriarchal religious discourse 21-

Intihal Taraması/Plagiarism Detection: Bu makale intihal taramasından geçirildi/This paper was checked for plagiarism. Etik Beyan/Ethical Statement: Bu çalışmanın hazırlanma sürecinde bilimsel ve etik ilkelere uyulduğu ve yararlanılan tüm çalışmaların kaynakçada belirtildiği beyan olunur/It is declared that scientific and ethical principles have been followed while carrying out and writing this study and that all the sources used have been properly cited (Mustafa Sarmıs).

Geliş/Received: 22 Mayıs/May 2021 | Kabul/Accepted: 01 Temmuz/July 2021 | Yayın/Published: 20 Eylül/September 2021 Atıf/Cite as: Mustafa Sarmış, "Selefí Din Anlayışlarının Psiko-Sosyal Olumsuz Yansımaları = Psycho-Social Negative Reflections of Salafi Understandings of Religion", Eskiyeni 44 (Eylül/September 2021), 433-460. https://doi.org/10.37697/eskiyeni.940878 CC BY-NC 4.0 | This paper is licensed under a Creative Commons Attribution-NonCommercial License 
Traditional education methods. When these features are analyzed in detail, it is understood that these approaches have factors that may negatively affect individuals and groups in many ways. However, Salafism is approached mostly as a negative structure by considering radical/jihadist Salafi movements in researches prevent us from seeing what kind of serious negative consequences of these understandings of religion have caused in the history of Islam and today, and what kind of problems they may cause in the future. Therefore, it is an important result that these understandings of religion should be carefully examined by believers.

\section{Keywords}

Sociology of Religion, Salafi Understandings of Religion, Salafism, Salafi Groups, Fundamentalism, Psycho-Social Negative consequences

\section{Öz}

\section{Selefî Din Anlayışlarının Psiko-Sosyal Olumsuz Yansımaları}

Bu makalenin temel iddiası, Selefî din anlayışlarının psikolojik ve sosyolojik (psiko-sosyal) açıdan birçok olumsuz sonuca yol açtığı, aynı zamanda bu unsurların sadece Selefilik ve Selefî gruplarla ilgisi olmadığı, dolayısıyla genel olarak çoğu Müslüman birey ve grubun inanç ögeleriyle ilişkili olduğudur. Bu kapsamda makalenin amacı, Selefî düşünceyi karakterize eden birçok farklı özellik olsa da onun din anlayışlarına yönelik geçmiş dönemde ve günümüzde ortaya çıkmış, aynı zamanda gelecekte de gün yüzüne çıkabilecek karşılıklı olarak birbirini etkileyen psiko-sosyal olumsuz özellikleri açığa çıkarmaktır. Makalede interdisiplinler bir yöntem üzerinden araştırma ve değerlendirme yapılmaktadır. Bu çerçevede farklı disiplinlere ait Selefî din anlayışlarının anlaşılmasını sağlayacak temel bilgiler ve tartışma konuları Din Sosyolojisi'nin araştırma alanlarıyla ilişkili bir biçimde ele alınmaktadır. İlk olarak Selefî din anlayışlarının psiko-sosyal açıdan olumsuz sonuçlar doğurabilecek özellikleri ve temel tutumları betimlenmiş, daha sonra bu tutumlar ayrı maddeler hâlinde sıralanarak onların yol açabileceği olumsuz etkiler zincirleme etki çerçevesinde nedensonuç ilişkisi sunularak açıklanmaya çalışılmıştır. Araştırma neticesinde Selefî din anlayışlarının olumsuz sonuçlar doğurabilecek özelliklerinin şunlar olduğu görülmüştür: 1-Sosyokültürel antropolojik yaklaşımın dikkate alınmaması 2-Temel seviyede sabit bir iman ve din anlayışı 3-Zâhirî/literal yaklaşım 4-İman-amel bütünlügü 5-Aklın dinî konuları kavrayamayacağı 6-Kur'an'ın mahlûk olmaması 7-Dinî metinler üzerinden hayatı inşa etme 8-Asr-1 saâdet dönemiyle sınırlı kalma 9-Dilin kutsanması 10-Tarih ve geleneğe karşı duruş 11Post/modern sorunlara geçmiş üzerinden çözüm arama 12-Bid'at karşıtlığı 13-Tek hakikatçi söylem 14-Dinî bilginin mutlaklaştırılması 15-Kültürel inşaya karşı duruş 16-Dinî otoriteleri kutsallaştırma 17-Tebliğ misyonu 18-Ümmetçilik anlayışı 19-Dârülharp söylemi 20-Ataerkil dinî söylem 21-Geleneksel eğitim yöntemleri. Bu özellikler ayrıntılı bir şekilde analiz edildiğinde söz konusu yaklaşımların kişi ve grupları birçok yönden olumsuz etkileyebilecek unsurlara sahip olduğu anlaşılmaktadır. Fakat araştırmalarda çoğunlukla radikal/cihatçı Selefî hareketler dikkate alınarak Selefîliğin olumsuz bir yapılanma olarak ele alınması, söz konusu din anlayışlarının İslâm tarihi içerisinde ve günümüzde ne tür ciddi olumsuz sonuçlara yol açtığını ve gelecekte de ne tür sorunları ortaya çıkarabileceğini görmemize engel olmaktadır. Bundan dolayı bu din anlayışlarının inananlar tarafından dikkatle incelenmesi gerekliliği önemli bir sonuç olarak karşımıza çıkmaktadır.

\section{Anahtar Kelimeler}

Din Sosyolojisi, Selefî Din Anlayışları, Selefîlik, Selefî Gruplar, Fundamentalizm, Psiko-Sosyal Olumsuz Etkiler 


\section{Giriş}

Selefî din anlayışları ayrıntılı bir şekilde analiz edildiğinde; bu yaklaşımların İslâm'ın anlaşılması ve yorumlanmasında, dindarlığın içerik ve biçim açısından farklı boyutlarla ilişkisinde, bireysel ve toplumsal hayatın çeşitli düzeylerde inşasında oldukça önemli niteliklere sahip olduğu görülmektedir. Ayrıca bu düşünceleri inşa eden temel özelliklerin genel olarak Sünnî/Şî̂ düşünceyi kapsayan geniş bir yapı içerisinde yer aldığını söylememizin mümkün olması, ${ }^{1}$ bu konunun İslâm dünyası ve ülkemiz açısından ne kadar dikkate değer olduğunu bizlere göstermektedir. Bu açıdan söz konusu din anlayışlarının temel kodları ayrıntılı bir şekilde analiz edilerek bu düşüncelerin tüm yönleriyle nasıl etki oluşturduklarının gösterilmesi önemli bir konu olarak karşımıza çıkmaktadır. Fakat araştırmalarda çoğunlukla radikal/cihatçı Selefî hareketler dikkate alınarak Selefîliğin olumsuz bir yapılanma olarak ele alınması, bu din anlayışlarının İslâm tarihi içerisinde ve günümüzde ne tür ciddi olumsuz sonuçlara yol açtı̆̆ını ve nasıl bir yayılım gösterdiğini, aynı zamanda gelecekte de ne tür sorunları ortaya çıkarabileceğini anlamamıza engel olmaktadır. Bu kapsamdan hareketle bu makalenin temel iddiası, Selefî düşünceyi inşa eden din anlayışlarının ve bu inanışlara bağlı olarak oluşan temel tutumların psikolojik ve sosyolojik (psiko-sosyal) açıdan birçok olumsuz sonuca yol açtı̆̆ı̆, aynı zamanda bu unsurların sadece Selefîlik ve Selefî gruplarla ilgisi olmadığı dolayısıyla genel olarak çoğu Müslüman birey ve grubun inanç ögeleriyle ilişkili olduğudur. Bu çerçevede bu makalenin amacı, Selefî düşünceyi karakterize eden birçok farklı özellik olsa da onun din anlayışlarına yönelik geçmiş dönemde ve günümüzde ortaya çıkmış, aynı zamanda gelecekte de gün yüzüne çıkabilecek karşılıklı olarak birbirini etkileyen psiko-sosyal olumsuz özellikleri açığa çıkarmaktır. Böylece Müslümanların ilgili konuları sadece bir inanç meselesi olarak göremeyecekleri, esasında bu inançların psiko-sosyal yönleriyle birlikte ele alındığında söz konusu olumsuz yansımaların ne kadar hayati derecede önemli olabileceği ve Müslümanları geniş bir çerçevede nasıl kuşattığı gösterilebilecektir.

Bu makalede interdisiplinler bir yöntem üzerinden araştırma ve değerlendirme yapılmaktadır. Bu çerçevede Din Antropolojisi'nde dinin kültürel/yerel algılanma ve yaşanma biçimleri, Din Psikolojisi'nde Tanrı tasavvurları, dindarlı̆̆ı etkileyen faktörler ve bireysel dinî algılama biçimleri, Din Felsefesi'nde din dili ve dinî sembolizm,

Mustafa Öztürk, “Zâhirî-Literalist Anlayışın İslam Düşüncesindeki ve Çağdaş Selefîlikteki İzdüşümleri”, Zâhirî ve Selefî Din Yorumu, ed. Sönmez Kutlu (İstanbul: Kuramer, 2019), 295; M. Ali Kirman, "Sekülerleşme Perspektifinden Dinî ve Seküler Fundamentalizmler", Uluslararası Sosyal Araştırmalar Dergisi 1/2 (2008), 283-284. Selefîliğin Şî̂lik içerisindeki tezahürleri hakkında bk. Habip Demir, "Çağdaş Şiî Islah Düşüncesinde Selefî Etkiler: Şerîat Senglecî Örneği", Hitit Üniversitesi İlahiyat Fakültesi Dergisi 19/1 (2020), 245-278. Avrupa Müslümanlarında da temelde Selefî din anlayışlarının genel kabul gördüğüne dair bk. Jocelyne Cesari, "Ethnicity, Islam, and les Banlieues: Confusing the Issues”, SSRC (Kasım 2005), 6; Ahmet Kavas, “Avrupa Selefîliği”, Tarihte ve Günümüzde Selefilik, ed. Ahmet Kavas (İstanbul: Çınar Matbaası, 2014), 615-657. Arap dünyasındaki Selefî hareketlerin geniş kapsamı hakkında bk. Beşîr Mûsâ Nâfi' - İzzuddin Abdu'l-Mevla - ElHevvâs Takıyye (ed.), Arap Dünyasında Selefilik ve Selefi Hareketler, çev. Nurullah Çakmaktaş (İstanbul: Yarın Yayınları, 2016). 
Tefsir'de Kur'an'ın evrenselliği-tarihselliği ve dinî metinlerin lafzîlliteral-te'vile dayalı okuma biçimleri, Kelâm'da Ku'ran'ın mahlûk olup olmaması, Hadis ve Fıkıh'ta ehl-i eser/ehl-i re'y farklılaşması, Tasavvufta zâhirî-bâtınî/derinlikli yorumlama biçimleri başta olmak üzere ayrıca bu konular merkezinde yer alan diğer meseleler de dikkate alınarak tüm bu hususlar Din Sosyolojisi'nin araştırma alanlarıyla ilişkili bir biçimde ele alınmaktadır. Din Sosyolojisi'ndeki konular ise genel olarak dinin modern ve postmodern dünyadaki yaşanma biçimleri ve Selefî gruplarda gözlemlenen çeşitli dinî algılamalar ve uygulamalar kapsamında değerlendirmeye alınmakta, fakat sadece bu konularla yetinilmeyerek işlenen konular bağlamında birçok farklı husus da göz önünde bulundurulmaktadır. Bu şekilde bir yöntem izlenmesinin sebebi, hem Selefî din anlayışlarını inşa eden itikadî ve ideolojik teorik altyapının hem de Selefî grupların yapısal özelliklerinin ve uygulamalarının çok yönlü bir kapsama sahip olmasıdır. Dolayısıyla Selefî düşüncenin çok yönlü ve katmanlı bir özellik arz etmesi onun anlaşılmasını sağlayacak yöntemin birçok alandan faydalanmasını zorunlu kılmaktadır. Bundan dolayı eksik ve indirgemeci açıllamalarla karşılaşmamak, en önemlisi Selefî düşüncenin ne olduğundan daha ziyade onun olumsuz yansımalarını doğru bir şekilde gözler önüne serebilmek için böyle bir yönteme başvurmanın daha doğru analiz ve sonuçların elde edilebilmesi açısından önemli olduğunu vurgulamamız gerekir.

Makalede öncelikle Selefî din anlayışlarının psiko-sosyal açıdan olumsuz sonuçlar doğurabilecek özellikleri ve temel tutumları genel olarak betimlenmiş, daha sonra söz konusu bu tutumlar ayrı maddeler hâlinde sıralanarak onların yol açabileceği olumsuz etkiler zincirleme etki çerçevesinde neden-sonuç ilişkisi sunularak açı̆̆a çıkarılmaya çalışılmışıı. Hiç şüphesiz ki söz konusu tutumların neden olabileceği bu makalede yer almayan farklı sonuçların var olması muhtemeldir; fakat makale sınırları çerçevesinde sadece öne çıkan özellikler ve etkilerin dikkate alındığını belirtmek gerekir. Selefî tutumların olumsuz etkileri açıklanırken özellikle Din Sosyolojisi ve Din Psikolojisi alanında fundamentalizmin ve Selefî din anlayışlarının anlaşılmasına dair çeşitli konular bağlamında gerçekleştirilmiş empirik araştırma bulgularından faydalanılmıştır. Fakat ilgili araştırmalarda çoğunlukla spesifik konuların işlenmesi, Selefî düşünceye ait tüm tutumları ortaya çıkarmamakta dolayısıyla onların olumsuz etkilerini dar bir alan içerisinde bırakmaktadır. Bundan dolayı bu makalede araştırma bulguları sunulmayan olumsuz etkiler, ilgili disiplinlerin elde etmiş oldukları bilgilerden faydalanılarak daha çok teorik düzeyde yorumlamaya dayalı açıklama ve değerlendirmeler üzerinden yapılmıştır.

Konuyla ilgili literatür incelendiğinde ülkemizde Selefî düşünceyi ve yapılanmayı araştıran birçok makale, tez ve kitap çalışması bulunduğu görülmektedir. Söz konusu araştırmalar daha çok Selefî inanç kodlarını ortaya çıkarmaya çalışan Temel İslâm Bilimleri'ne ait araştırmalardan oluşmaktadır. Bu araştırmalar çoğunlukla Selefî düşünceyi inşa eden itikadî meselelere odaklanmaktadır. Bunların dışında Mezhepler Tarihi bağlamında yapılan araştırmalar Selefîliğin tarihi süreçteki seyrini ve değişimlerini ele almakta, ayrıca günümüz dünyasında Selefî hareketleri betimlemeye 
çalışmaktadır. Selefîliği sosyolojik çerçevede ele alan araştırmalar ise daha çok fundamentalizm üzerinden şiddet üreten radikal/cihatçı gruplar kapsamında ele almaktadır. İngilizce yayımlanan yabancı araştırmalara genel olarak bakıldığında, daha çok hem Müslüman hem de Batı ülkelerindeki Selefî grupların özellikleri, bilhassa ülke içi yapılanmaları ve uygulamalarının incelendiği görülmektedir. Dolayısıyla tüm bu literatür göz önüne alındığında; söz konusu araştırmalarda bu makalede uygulanmaya çalışıldığı şekilde interdisipliner bir yaklaşım sergilenmemesi, Selefî din anlayışlarının hangi temel tutumlara sahip olduğunun sistematik ve öz bir yaklaşımla açıklanmaması, söz konusu tutumların olumsuz yansımalarının neden-sonuç ilişkileri çerçevesinde açı̆̆a çıkarılmasını sağlayacak bir yöntem uygulanmaması, çoğunlukla benzer konular ele alınarak meselenin dikkat çekilmesi gereken farklı yönlerine vurgu yapılmaması ve tüm bu ayırıcı özelliklerin bütüncül bir yaklaşımla sunulmaması bu makaleyi diğer araştırmalardan ayırmakta ve önemli kılmaktadır.

\section{Selefî Din Anlayışlarının Genel Özellikleri}

Çoğunlukla erken dönem din anlayışını temsil eden Selefîliğin tarihsel sürecine bakıldığında, öncelikle Ahmed b. Hanbel (öl. 241/855), İbn Teymiyye (öl. 728/1328), İbn Kayyim el-Cevziyye (öl. 751/1350) ve Muhammed b. Abdülvehhâb (öl. 1206/1792) gibi önemli isimler üzerinden Ashâbü'l-Hadîs ve Hanbelîlikle özdeşleştirilen itikadî/fikhî mezhepsel bir yaklaşım öne çıkmaktadır. Burada yer alan temel İslâmî anlayışların genel olarak çoğu Selefî oluşum tarafından benimsendiğini vurgulamak gerekir. Bir diğer Selefîlik anlayışı, 19. yüzyılın ikinci yarısıyla birlikte Selefîliğin çağdaş İslâmcı bir akım olarak ele alınması hususu karşımıza çıkar ki burada inceleme alanı daha çok modern Selefî gruplara yöneliktir. Bu grupların birbirinden farklı niteliklere sahip olması bu Selefî akım/grupların çoklu tasnifler üzerinden incelenmesini gerekli kılmaktadır. Ancak söz konusu oluşumların genel olarak belli başlı niteliklere sahip oldukları göz ardı edilmemelidir. Bu noktada modern Selefî yapılarda vurgulanması gereken en önemli yön, onların konjonktürel siyasal yapılarla ilgili tutumları ve ilişki biçimleridir. Bu çerçevede otoriteyle ve toplumla genel anlamda uyumluluk arz eden gruplar ile köklü dönüşüm/değişim hedeflerine bağlı olarak hem toplumla hem de devletle uyuşmayan bir yaklaşımı benimseyen ve şiddet üreten radikal grupların aynı olmadığı bilhassa vurgulanmalıdır. ${ }^{2}$ Son olarak, hem itikadî/fikhî mezhep olarak hem de çağdaş İslâmcı bir hareket biçiminde karşılaşılan durumlar başta olmak üzere geçmişte ve günümüzde Selefî düşünceyle ilişkilendirilebilecek birçok hususu bir söylem ve zihniyet olarak ele alan bir yaklaşım yer almaktadır. Dolayısıyla tarihi süreç içerisinde var olan 'Selefîlik', modern dönemde ortaya çıkan ‘Selefî gruplar' ve ‘Selefî din anlayışları' arasında bir ayrımın karşımıza

Mehmet Ali Büyükkara, “Türkiye'de Radikal Dini-Siyasal Akımlar”, Demokrasi Platformu (Türkiye'de Tarikatlar ve Cemaatler - III) 2/8 (2006), 107-110. Radikal bir tavra sahip olmayıp ılımlı Selefî yaklaşımı benimseyen bireylerin de Selefî inanç ögelerinin çoğunu kabul ettiklerine dair bk. Nazırhan Şener, Türkiye'de Dinin Selefi İnşası (Ankara: Ankara Üniversitesi, Sosyal Bilimler Enstitüsü, Yüksek Lisans Tezi, 2020), 279-280. 
çıktığını belirtmeliyiz. ${ }^{3}$ Makalenin sınırları çerçevesinde bu tasnifte yer alan her bir unsuru ayrı ayrı açıklamak mümkün olmadığı için, burada Selefilliğe ve Selefî gruplara ait en önemli özellikler üzerinden 'Selefî düşünce'nin açığa çıkarılmasını sağlayan genel bir tip sunulmaya çalışılacaktır.

Selefî din anlayışları ve fundamentalizmin özelliklerini analiz eden araştırmalar karşılaştırıldığında, bu iki yaklaşım arasında sıkı bir ilişki görülmektedir. Bu açıdan Selefî düşüncenin özellikleri açıklanırken fundamentalizmi anlamaya yönelik gerçekleştirilmiş psikolojik ve sosyolojik açıklamalardan da faydalanılacaktır. Bu araştırmalara bakıldığında fundamentalizmin farklı açılardan ele alınabilecek çeşitli yönlere sahip olduğu görülmektedir. Psikoloji alanında, fundamentalizmin dindarlığın bir boyutu veya dinî bir yönelim olduğu bu çerçevede iç güdümlü ve dış güdümlü, arayışsal ve fundamentalist dinî yönelimlerin karşılaştırılarak ele alındığı, dinönyargı ilişkisinin ve ötekine yönelik olumsuz tutum ve davranışları açılamakta fundamentalizmin işlevsel olduğu, ayrıca otoriter bir kişiliği göstermesi açısından onun bir kişilik türü olarak ele alınabileceğine dair araştırmaların yapıldığı görülmektedir. Sosyal psikoloji alanında, özellikle otoriteryen boyun eğme, saldırganlık ve gelenekçiliği yansıtması açısından sağ-kanat otoritercilik ve fundamentalizm ilişkisine yönelik açıklamalar yapılmaktadır. ${ }^{4}$ Sosyoloji alanında, fundamentalizmi doğuran sosyal etkenlerin kaynakları ve onun farklı dinlerde/dinî yapılarda nasıl çeşitlilik gösterdiği, özellikle modern dünyanın sosyal ve dinî alanda ortaya çıkardığı birçok sorun nedeniyle reaksiyoner bir tavır olarak en başta siyasal bir karşı duruş olmak üzere çeşitli yönleriyle farklı fundamentalist yapıların nasıl oluştuğu ve özelliklerine dair geniş bir kapsamın bulunduğu görülmektedir. ${ }^{5}$

3 Mine Demirbilek - Hakan Atalay, “Türkiye'de Selefillik Araştırmalarında Rastlanan Bazı Sorunlar", Journal of Islamic Research 29/2 (2018), 448-459; Mohamed Ali, "Understanding Salafis, Salafism and Modern Salafism", İslâmiyyât 41/1 (2019), 125-136.

4 bk. Bob Altemeyer - Bruce Hunsberger, "Authoritarianism, Religious Fundamentalism, Quest and Prejudice", The International Journal for the Psychology of Religion 2/2 (1992), 113-133; Brian Laythe vd., "Religious Fundamentalism as a Predictor of Prejudice: A Two-Component Model", Journal for the Scientific Study of Religion 41/4 (2002), 623-635. Söz konusu yaklaşımların neler olduğu ve hangi araştırmac1lar tarafından açıklandığı hakkında geniş bilgi için bk. Abdulvahid Sezen, "Dinsel Fundamentalizm ölçeğinin Türkçe Çevirisinin Geçerlik ve Güvenirlik Çalışması", SÜifD 30 (2010), 135-140. Sağ-kanat otoriterciliğin özelliklerinin fundamentalizmi açıklamaya yönelik önemli bilgiler sunduğunu göstermesi açısından bk. Özgür Güldü, "Sağ Kanat Yetkeciliği Ölçeği: Uyarlama Çalışması”, Ankara Üniversitesi Sosyal Bilimler Enstitüsü Dergisi 2/2 (2011), 27-33.

5 Fundamentalizme dair geniş literatürün ve araştırma konularının görülebileceği bazı çalışmalar için bk. Martin E. Marty - R. Scott Appleby (ed.), Fundamentalisms Comprehended (Chicago: University of Chicago Press, 1995); Simon A. Wood - David Harrington Watt (ed.), Fundamentalism: Perspectives on a Contested History (Columbia, SC: University of South Carolina Press, 2014); Hafize Şule Albayrak, Hristiyan Fundamentalizmi (İstanbul: Marmara Üniversitesi, Sosyal Bilimler Enstitüsü, Yüksek Lisans Tezi, 2006). Fundamentalizmin İslâm'la ve İslâmî gruplarla ilişkisini göstermesi ve ilgili tartışmalar için bk. Necdet Subaşı, “Fundamentalizm, İslam ve Hayat”, İslam Araştırmaları 8/3-4 (1995), 250-262; Ayşe Çelik Sağır, Türkiye'de Günümüz Dini Köktenciliğinin İdeolojisi: Tevhid Dersleri ve Selefiyye Siteleri Örneği (İstanbul: Marmara Üniversitesi, Sosyal Bilimler Enstitüsü, Yüksek Lisans Tezi, 2013); Özgür Kellecioğlu, Psikopolitik Yönden İslamcı Fundamentalizmin İncelenmesi (Ankara: Kara Harp Okulu, Savunma Bilimleri Enstitüsü, Yüksek Lisans Tezi, 2007). 
Bu çerçevede Selefî din anlayışları ve fundamentalizmin birbirleriyle ilişkili olan yönleri birlikte ele alınarak Selefî düşüncenin genel özelliklerinin psikososyal açıdan olumsuz sonuçlar doğurabilecek belli başlı tutumları şu şekilde betimlenebilir:

Asr-1 saâdet dönemini temel alan Selefî düşünce, en güvenilir yolun eskilerin (sahâbe, tâbiîn, tebeu't-tâbiîn) gitmiş olduğu 'mü'minlerin yolu' olduğunu savunmaktadır. Zâhirî bir yaklaşımla Kur'an'ı ele alarak lafzîlliteral bir okuma üzerinden dinî metinlere yaklaşmakta ve te'vilden uzak durmaktadır. Aklın yetersizliği düşüncesinden hareketle Kur'an ve Sünnet'e sorgusuz teslimiyet göstermekte ve İslâmî geleneğe bağlılık üzerinden muhafazakâr bir yaklaşım sergilemektedir. İman-amel bütünlügünü öne çıkararak kişilerin imanlı sayılabilmesi için her dinî emrin yerine getirilmesini şart koşmaktadır. Dinî düşüncedeki deformasyonu önlemek ve İslâm'1 yabancı unsurlardan temizlemek için bid'at karşıtlı̆̆ üzerinden bir söylem geliştirmekte, buna dayalı olarak ihyacı bir tavırla geleneksel halk dindarlığıyla bir çatışma içerisine girmektedir. Kur'an'ın doğru bir şekilde anlaşılmasını sağlayacak tarihsel bağlamı çoğu zaman arka plana atmakta, metnin derinliğine nüfuz etmeye lafızcılık yaparak karşı çıkmaktadır. Özellikle itikadî konular başta olmak üzere dinî ögeler akli ve eleştirel bir yaklaşıma tabi tutulmadı̆̆ı için fideist bir yaklaşım sergilenmekte, dolayısıyla bu yaklaşım dogmatizm ve fanatizme götürmektedir. Modern dünyanın mikro/makro sorunlarına karşı reaksiyon göstererek geçmişe/öze dönmek istemektedir. Asr-1 saâdet döneminin günümüze taşınması düşüncesinden hareketle şu an içinde bulunulan post/modern dünyanın reel gerçekliğiyle uyuşmayan bir tarih algısıyla düşüncelerini ortaya koymaktadır. Onun bu yönüyle tarih karşısında edilgen bir tutum takındığı, gelecek idealini ileride değil geçmişte araması sebebiyle tarihi yeniden inşa etmek gibi bir misyonunun olmadığı görülmektedir. İslâm dinini neredeyse tümüyle Arap kültürüyle özdeşleştirerek İslâm'ın hedef ve ilkelerinin tüm zamanlarda ve farklı toplumlarda yerel koşullarla yeniden inşa edilmesine karşı durmaktadır. Bu açıdan geleneğin dışına çıkmak her zaman olumsuz bir olgu olarak kabul edilmekte ve kültürel ögeler dine karşı bir tehdit olarak algılanmaktadır. Selefi sâlihînin görüş ve eserlerinin otorite olarak görülmesinden dolayı onlar bir bakıma kutsallaştırılmaktadır. Kendi ideolojik dinsel amaçlarını gerçekleştirmek için Peygamber başta olmak üzere dinî kişilikleri, kaynakları, otoriteleri ve yapıları araçsal bir şekilde kullanmaktadır. Dolayısıyla mutlak hakikatin Selefî düşünceye ait olduğu savunularak mezhepsel/grupsal tekelcilik yapilmakta ve buna dayalı olarak insanlara hazır kurtuluş reçeteleri sunulmaktadır. Bu yaklaşımın sonucu olarak inşa edilen fonksiyonel karizmalar üzerinden sorgulanamaz liderler ve onların kitapları aracıl1ğıla özellikle modern dönemde yeni Selefî grupların gün yüzüne çıtığı görülmektedir. Kendilerini fırka-i nâciye olarak gören bu gruplar diğer düşünceleri dışlayıcı bir söylem ve tutumla ötekileştirmekte, dolayısıyla bu yaklaşım çatışmalara sebebiyet vererek bu grupları şiddet üreten radikal formlarla bütünleştirebilmektedir. ${ }^{6}$ 


\section{Selefî Düşünceye Ait Temel Tutumların Psiko-Sosyal Olumsuz Yansımaları}

Selefî din anlayışlarının genel özellikleri ayrıntılı bir şekilde analiz edildiğinde bu yaklaşımın birçok olumsuz sonuca yol açan çeşitli düşünceleri ve tutumları içerisinde barındırdığı görülmektedir. Bu çerçevede bu düşünceyi inşa eden temel anlayışlardan hareketle ne tür sorunların ortaya çıktığını ve çıkabileceğini birbirini tetikleyen neden-sonuç ilişkileri çerçevesinde maddeler hâlinde şu şekilde sıralamak mümkündür:

\subsection{Sosyo-Kültürel Antropolojik Yaklaşımın Dikkate Alınmaması $\rightarrow$ Dinin Geli- şimsel Boyutunun Görülmemesi $\rightarrow$ Kurumsallaşmış Dinî ögelerin Kutsallaştırılması}

Selefî düşüncenin toplum, kültür ve zamanla ilişkisini gösteren en önemli yöntemsel yaklaşımın, ya dinin sosyo-kültürel antropolojik düzeyde insani bir çaba üzerinden ya da ilahi bir buyruk üzerinden temellendirilmesi olduğunu söyleyebiliriz. Dinin insani bir çaba olarak hayatın içerisinde yer alması, kutsalın tezahürünü farklı zaman, kültür ve birikimlere göre çeşitlendirecektir. Dolayısıyla insanın ve toplumun birçok yönden gelişimiyle birlikte dinin de aynı şekilde kendisini değişime tabi tutması normal bir durum olarak karşımıza çıkacaktır. Dinin ilahi buyruk üzerinden anlaşılması ise, dinin insan tarafından değişime ve gelişime tabi tutulmasını engellemektedir. Selefî yaklaşımda dinin kaynağı Allah'tır ve örnek uygulayıcısı ise Peygamber'dir. Dolayısıyla orada insani bir çabadan bahsetmek mümkün değildir. Fakat bu tavır, hem vahyin inişi esnasındaki mevcut toplumun özelliklerinin vahiyle irtibatını dikkate almamakta hem de dinin zaman içerisinde kurumsallaşan birçok yönünün insani tarafını görmezden gelerek mevcut yaşanan dinin tümünü ilahi bir bakışla değerlendirmektedir. ${ }^{7} \mathrm{Bu}$ durum, içinde bulunulan her türlü dinî unsurun ya kutsal bir nitelikle bütünleşmesine ya da sonradan dine eklenenlerin bid'at olarak görülmesine yol açmaktadır. Selefî tavır bid'at üzerinde yoğunlaşmasına

49; Ferhat Koca, “İslâm Düşünce Tarihinde Selefîlik: Tarihsel Serüveni ve Genel Karakteristiği”, İlahiyat Akademi 1/1-2 (2015), 15-70; Mehmet Evkuran, "Bir Kriz Teolojisi ve Toplumsal Hareket Olarak Selefîlik -Selefî İdeoloji ve İslâm Dünyasındaki Etkileri Üzerine Bir Analiz-”, İlahiyat Akademi 1/1-2 (2015), 71-90; Mehmet Kubat, “Selefî Perspektifin Tarihselliği”, İslami Araştırmalar Dergisi 17/3 (2004), 235-251; Hanifi Şahin, “İhya Islah Hareketleri ve Selefîlik İrtibatı”, e-makâlât Mezhep Araştırmaları 9/1 (2016), 1-37; Temel Yeşilyurt, “İslam İmanı Fundamentalizmi Destekler mi?”, Türkiye’nin Güvenliği Sempozyumu, ed. Orhan Kılıç - Mehmet Çevik (Elazı̆̆: Fırat Üniversitesi, 2001), 763-770; Quintan Wiktorowicz, “Anatomy of the Salafi Movement", Studies in Conflict and Terrorism 29/3 (2006), 207-239; Mehmet Ali Kirman, “Hakikat Tekelciliği ve Dinî Partikülarizm”, Çukurova Üniversitesi İlahiyat Fakültesi Dergisi 19/2 (2019), 330-346; Mehmet Ali Kirman, "Sekülerleşme Perspektifinden Dinî ve Seküler Fundamentalizmler", 274-291; Bahram Hasanov, "Dinî Fundamentalizmi Ayakta Tutan Temel Faktörler”, AİBÜ Sosyal Bilimler Enstitüsü Dergisi 6/3 (2016), 241-258; Mustafa Acar, "Radikal Selefi Zihniyete Bir Reddiye”, Muhafazakâr Düşünce 2/6 (2005), 163-196; Murat Beyazyüz - F. Sevinç Göral Alkan - Erol Göka, "Fundamentalizmin Psikolojisi", Avrasya Dosyası 13/3 (2007), 355-384.

7 Kişi ve toplumların hayatını her yönden etkileyen bir özelliğe sahip olan Tanrı tasavvurlarının oluşumunda bireysel ve sosyal aynı zamanda kültürel ve siyasal etkiler söz konusu olmasına rağmen kişi ve grupların söz konusu Tanrı tasavvurlarını kutsallaştırarak araçsallaştırmaları hakkında bk. Mahmut Ay, “Tanrı Tasavvurlarının Politik Tasarımlara Yansıması”, AÜIFD 46/2 (2005), 107-130. 
rağmen işin esası zaman içerisinde kurumsallaşan birçok dinî ögeyi görmezden gelerek subjektif bir yönelimle kendi ideolojik yaklaşımlarını dinin kendisi olarak kabul etmektedir. Nihayetinde dinin varoluşu ve gelişiminde insanın ve toplumun dikkate alınmaması sebebiyle bireyin iradesinin, kişiliğinin, potansiyelinin ve yaratıcılığının dinî alanda devre dışı bırakılması sonucu ortaya çıkmaktadır. Bu süreçte dikkat çeken en önemli hususun 'insanın değersizleşmesi' olduğunu vurgulamak gerekir. Sosyolojik açıdan ise kültürün gelişmesinin ve yenilenmesinin yok sayılması gibi bir durumla karşı karşıya kalınmasına neden olunmaktadır.

\subsection{Temel Seviyede Sabit Bir İman ve Din Anlayışı $\rightarrow$ Bireysel Dinî Algılama Bi- çimlerinin Farklılığını Dikkate Almama $\rightarrow$ İmanın Dinamik Boyutunun Göz Ardı Edilmesi}

Akidenin 'açık ve kolay olması' gerektiği düşüncesinden hareketle naslar üzerinde akıl yürütmeye ve te'vile karşı duran Selefî yaklaşım, bu tavrıyla dinî grup ve mezhepler tarafından Kur'an'ın ideolojik bir şekilde yorumlanmasının önüne geçmeyi hedeflemektedir. ${ }^{8}$ Fakat onun bu tavrının tüm bireylerin aynı temel seviyede olduğu ön kabulüyle hareket etmesi ve ayrıca çoğunlukla somut bir din tasavvuru üzerinden akideyi inşa etmesi inananların tümünü belli bir kalıp üzerinden tanımlamaya götürmektedir. Bu durumun gelişime kapalı bir din anlayışını ve herkesin aynı düzeyde görülmesi gibi sorunlu bir bakış açısını ortaya çıkaracağı açıktır. Buna karşın Selefî tutumun kendi yaklaşımını evrensel bir pozisyonla özdeşleştirmesi psiko-sosyal açıdan birçok sorunu gündeme getirmektedir. Özellikle bireyin çeşitli faktörlere bağlı olarak yaşamı içerisinde karşılaştı̆̆ı birçok değişimin onun imanının farklı biçim ve içeriklere sahip olacağını göstermesine rağmen Selefî tutumun söz konusu değişimi dikkate almaması psikolojik bir olgu olarak karşımıza çıkan "iman gelişimi”"ni" anlamsız hâle getirmektedir. Bu problemli tutumun en dikkat çekici yansıması, realiteyle uyumlu olmayan birey ve toplum anlayışıdır. Hem bireysel dinî algılama biçimlerinin çok çeşitliliğini dışarıda bırakarak onları aynı seviyede eşitlemesi hem de kişileri iman gelişiminin ilk evrelerine özellikle somut düşünme biçimine sabitleyerek soyut ve derinlikli din anlayışlarından uzaklaşılmasına neden olması Selefî tavrın realiteyi göz ardı eden bir tutuma sahip olduğunu göstermektedir. Ayrıca ideolojilerden bağımsız bir anlayış biçimine vurgu yapması, bireyin toplum ve kültür içinde hayatı algıladığı gerçeğinin üstünü örtmektedir. Bu yaklaşım, toplum ve kültürden bağımsız bir din anlayışı geliştir-

Evkuran, “Bir Kriz Teolojisi...”, 73-74.

9 J. Fowler'ın "inanç gelişimi kuramı” ve bu kuramın fundamentalizmle ilişkili yönleri hakkında bk. Üzeyir Ok, "Biyografik Anlatıya Dayalı İnanç Gelişimi Biçimleri ve Nicel Ölçümler”, Çukurova Üniversitesi İlahiyat Fakültesi Dergisi 12/2 (2012), 126-134; Abdulvahid Sezen, "İman Gelişimi-Dinsel Fundamentalizm İlişkisi: Üniversite Öğrencileri Örneği”, DEÜİFD 28 (2008), 204-209. İman gelişimi ve fundamentalizm arasındaki ilişkiyi araştıran Batı'da ve ülkemizde yapılmış birçok empirik çalışmada iman gelişim seviyesi düşük olan kişilerde farklı nitelikteki fundamentalist tutumların yoğun bir şekilde gözlendiği belirtilmektedir. Söz konusu araştırmalar ve araştırmaların bulguları hakkında ayrıntılı bilgi için bk. Sezen, "İman Gelişimi-Dinsel Fundamentalizm İlişkisi”, 218-226. 
menin mümkün olamayacağı gerçeğini devre dışı bırakarak inanan kişiyi geleneğiyle karşı karşıya getirmektedir. Bu durum bireyin toplumsal gerçeklikten uzaklaşmasına ve en önemlisi kendi kültürüne yabancılaşmasına yol açmaktadır.

\subsection{Zâhirî/Literal Yaklaşım $\rightarrow$ Antropomorfik Tanrı Tasavvuru $\rightarrow$ Tanrı'nın Doğ- ru Bir Şekilde İçselleştirilememesi $\rightarrow$ Dinî Psikolojik Tatmin Eksikliği $\rightarrow$ Sağlıksız Dindarlı $\rightarrow$ Bireysel ve Sosyal Dinî Gerileme}

Dinî metinlerin sadece literal anlamlarının kabul edilmesi ile Tanrı'nın özelliklerinin te'vil yapılmadan anlaşılmak istenmesi antropomorfik Tanrı tasavvurlarını ortaya çıkarmaktadır. Bu yaklaşım, Tanrı'nın tüm yönleriyle ele alınmasını engelleyerek ona dair derinlikli anlayışların önünü tıkamaktadır. ${ }^{10}$ Aynı zamanda Arap dili ve kültürünün özellikleri çerçevesinde anlatılan Tanrı'ya ait özelliklerin literal anlamlarının ötesinde yeni manalarla buluşmasına engel olmaktadır. ${ }^{11}$ Söz konusu bu yaklaşım biçimi Tanrı anlayışlarına dayalı olarak sağlıklı dinî tutumların önüne geçmekte, inananların Tanrı'yı yakından hissetmeleri ve onunla buluşmalarında ciddi sorunlara neden olmaktadır. Dolayısıyla Din Psikolojisi alanında yoğun bir şekilde ele alınan, kişinin dini daha doğru ve huzur içerisinde yaşamasını sağlayacak sağlıklı Tanrı tasavvurlarının inşa edilmesinde Selefî söylemin bu tavrının olumsuz sonuçlara yol açtığını söylemek mümkündür. Ayrıca bireyler tarafından otoriter din anlayışlarının oluşmasında Selefî tavrın Tanrı'yı ve onun emirlerini doğru bir perspektifle okuyamamasının, buna bağlı olarak sorunlu algılama biçimleri üretmesinin oldukça etki oluşturduğunu özellikle vurgulamak gerekir. Selefî söylemin zâhirî yaklaşımla ele aldığı Tanrı tasavvuru hem duygusal bağlanmayı olumsuz bir şekilde etkileyebilmekte hem de Tanrı'yla kurulan ilişkinin insanın iç dünyasıyla buluşmasına engel olabilmektedir. Bu durum hem diş güdümlü dindarlık yönelimini hem de otoriter Tanrı anlayışlarını ortaya çıkarmaktadır. ${ }^{12}$ Selefî düşüncenin bu yaklaşımından top-

10 Ehl-i re’y ve Selefî düşüncenin Tanrı tasavvurları hakkında bk. Hasan Ocak, "Klasik İslam Düşüncesinde İki Farklı Tanrı Tasavvuru", Türkiye Din Eğitimi Araştırmaları Dergisi 6 (2018), 125-141; Fethi Kerim Kazanç, "Eş'arî Kelam Sisteminde Allah Anlayışı ve Doğurduğu Sorunlar", X. Kelâm Anabilim Dalı Koordinasyon Toplantisı ve Tanrı Tasavvurları ve Sosyal Hayata Yansımaları Sempozyumu, ed. Ramazan Biçer - Süleyman Akkuş (Sakarya: Sakarya Üniversitesi İlahiyat Fakültesi Yayınları, 2005), 107-142.

11 'Din dili' çerçevesinde Tanrı'nın ve vahyin toplumla ilişkisini göstermesi açısından bk. Latif Tokat, "Dinin Sembolik Dili", Milel ve Nihal 6/1 (2009), 75-98.

12 Farklı Tanrı tasavvurlarının özellikleri hakkında bk. Faruk Karaca - Hızır Hacıkeleşoğlu, "Allah Tahayyüleri Ölçeği”, İlted: İlahiyat Tetkikleri Dergisi 54/2 (2020), 67-83. Tanrı tasavvurlarının oluşumunda nasıl kompleks bir yapının var olduğu ve farklı Tanrı tasavvurlarının ruh sağlığıyla ilişkisi hakkında bk. Sebastian Murken, "Tanrı'yla ílişki ve Ruh Sağlı̆̆ı- Bir Modelin Gelişimi ve Deneysel İncelemesi”, çev. Yusuf Macit, Çukurova Üniversitesi İlahiyat Fakültesi Dergisi 12/2 (2012), 299-316. W. James, G. W. Allport, E. Fromm ve A. Maslow'un sağlıkl1-hasta, iç güdümlü-dış güdümlü, hümaniter-otoriter, kendini gerçekleştiren-gerçekleştiremeyen dindarlık türlerinden faydalanılarak varoluşçu psikoloji anlayışı çerçevesinde Rollo May tarafından geliştirilen "sağlıkl1-sağlıksız dindarlık" yaklaşımı için bk. Özer Çetin, Rollo May Psikolojisinde Din ve Kişilik (İstanbul: İz Yayıncılık, 2019), 51-68, 74-82. Fundamentalist tavırlar sebebiyle ortaya çıkan 'kapalı fikirlilik' ve 'negatif duygusallık' durumlarını gösteren dindarlığın olumsuz boyutları ve biçimleri 
lumsal yapılar ciddi şekilde etkilenecektir. Zira duygu ve derinlikten yoksun bir Tanrı anlayışı, sosyal hayata aynı şekilde yansıyarak kültür ve medeniyetin sadece yüzeysel bir şekilde algılanmasına, sanatsal form ve içeriklerin orada kendine yer bulamamasına yol açacaktır.

Lafızcı anlayışın Tanrı'yı antropomorfik bir tarzda ve buna bağlı olarak daha çok onun aşkın yönüne vurgu yaparak ele alması, insan-Tanrı ilişkisinin kuvvetlenmesini büyük oranda engellemektedir. Tanrı'yı insanla bütünleşmiş bir şekilde ele alan dinî yaklaşımların, içkin bir Tanrı tasavvuruna bağlı olarak insan hayatının tüm yönlerini etkileyeceğini vurgulamak gerekir. Dolayısıyla bu yaklaşımda insanın çok önemli bir konumda bulunduğunu, insanı tanımanın da ancak kişinin kendi anlam dünyasını keşfetmesi ile gerçekleşeceğini, bu sebeple onun içinde bulunduğu değer ve kültür dünyasıyla birlikte var olması neticesinde bireyin kimliğini ve hayatını inşa eden toplumundan koparmayarak ona göre bir dinî anlayış geliştirmesine vurgu yaptığını söyleyebiliriz. Fakat insanın kendi içine yönelmek ve oradan kişinin kendini tanımasıyla birlikte Rabbe giden yeni yollar keşfetmek Selefî düşüncenin öne çıkardı̆̆ı ve benimsediği bir yöntem olarak karşımıza çıkmamaktadır. Zira Selefî yaklaşımda önemli olan husus, ilahi bir buyruk olarak gelen dinî emirleri sorgulamadan yerine getirerek Allah'a teslim olmaktır; değilse insanın kendi içine yönelmesi neticesinde elde edeceği hakikatler yanıltıcı olabileceği için oraya yönelmek kişiyi yanlış düşüncelere sevk edebilecektir.

Dinî meselelerin çoklu katmanlar ve farklı boyutlarıyla birlikte değerlendirilmesi, İslâm'ın farklı topluluklarda ve ilerleyen zamanlarda dinin farklı yorum biçimlerine kaynak oluşturduğunu göstermesi açısından önem arz etmektedir. Fakat Selefî zihniyetin dinî meseleleri zâhiri üzerinden ele alması nedeniyle dinî konular statik bir anlayışla ele alınmaktadır. Söz konusu bu yaklaşımın en olumsuz yansıması, dinin özüne doğru yol alınamadığı için zaman içerisinde kendi kendini körelten bir tutum sergilenmesidir. Zira dinî hakikatler hem bireyin tekâmülüne hem de zamana ve kültürel birikime bağlı olarak geliştirilmediği takdirde artık sadece var olanlarla yetinilmek zorunda kalınacak ve onlar da zaman içerisinde tükenip gidecektir. ${ }^{13}$ Bu sebeple Selefî söylemin 7. yüzyıl içerisinde ortaya konulan hakikatlerin ardında yeni bir gelişim göstermemesi hem bireysel hem de sosyal açıdan eksikliklere ve sorunlara yol açmaktadır.

\section{4. İman-Amel Bütünlüğü $\rightarrow$ Katı Ahlâkçı Tutum $\rightarrow$ Bireysel Dindarlık Biçimle- rinin Yok Sayılmas $\rightarrow$ Tek Tip Dindarlık}

İman-amel ilişkisini önceleyen Selefî tutum, bireylerin hangi şartlar içerisinde bir kişilik oluşturduklarını göz ardı ederek özellikle psiko-sosyal realiteyi devre dışı bırakmakta ve herkesin İslâm'ın emirlerini eksiksiz bir şekilde yerine getirme-

hakkında bk. Vassilis Saroglou, "Studying Religion in Personality and Social Psychology", Religion, Personality, and Social Behavior, ed. Vassilis Saroglou (New York: Psychology Press, 2014), 711.

13 bk. Ekrem Demirli, Şair Sûfiler - Mevlana, Yunus ve Niyazi-i Mısrî Üzerine İncelemeler (İstanbul: Sufi Kitap, 2018), 39-56. 
sini talep etmektedir. Fakat bu durum her bireyin aynı özelliklere sahip olduğu varsayımından hareket ettiği için kişisel farklılıkların yadsınması söz konusu olmakta, dolayısıyla bireyleri sınırlandıran ve onların özelliklerini göz ardı eden bu yaklaşım tek hakikatçi bir tutumla bireysel dindarlığın var olan görünümlerini yok etmektedir. Tabii bu durum dinî sosyaliteler içerisinde bireyin özgür iradesini ciddi şekilde devre dışı bırakarak herkesin belirli bir anlayışla özdeşleşmesi, daha da önemlisi bireylerin psiko-sosyal açıdan çatışmalarla karşılaşması sonucunu doğurmaktadır. Örneğin, insan için her zaman var olabilecek hata ve günahların psiko-sosyal karakteri tarihi süreç içerisinde görmezden gelinerek bu tür hataları işleyenler büyük günahlarla ilişkilendirilmiş hatta bu tür kişiler tekfir edilerek İslâm dışı olmakla itham edilmiş, tabii buna bağlı olarak şiddetli cezalar uygulanmış ve hatta öldürülmüşlerdir. Dolayısıyla iman-amel bütünlüğüne yönelik ortaya çıkan bu katı ahlâkçı tutumun olayların ardındaki gerçek olguları görememe gibi önemli bir eksiklik barındırdığı ve bu tutumun geçmişte Hâricîlik, günümüzde DAiş ve Taliban ${ }^{14}$ gibi birçok örnekte görüldüğü üzere şiddet eylemlerinin önünü açan bir niteliğe sahip olduğu anlaşılmaktadır.

Katı ahlâkçı tutum sergilenmesinin arka planında bedavacılar ile adanmış/bilinçli kişilerin birbirinden ayrılması düşüncesi yattığı görülmektedir. ${ }^{15} \mathrm{Bu}$ tavır yani kendisini adanmış/bilinçli görüp diğerlerinin öyle olmadığını düşünmek, hem kişinin diğer insanlara yönelik olumsuz bir bakışla yaklaşmasına hem de onun kendisini diğerlerinden üstün görme gibi sağlıksız bir kişiliğe sahip olmasına neden olmaktadır. Bu durum ise kişinin kendi inancı ve amellerinden daha ziyade başkalarının dindarlıklarıyla ilgilendiğini göstermektedir. Aynı zamanda bireylerin bu tavır üzerinden kendilerini diğerlerinden ayırması neticesinde karşımıza çıkan önemli durumlardan birisi, kişilerin bu niyetle dinî gruplara katılmasıyla birlikte söz konusu grupların sağlam üyelere sahip olarak yapılarını güçlendirmeleridir. Bu tutumun en dikkat çeken sonucu ise bireylerin inançları gereği yerine getirdikleri dinî emirlerin sağlam bir yapı inşa etmesi neticesinde orada bireysel dinî yaklaşımların kendisine yer bulamaması olduğu ifade edilebilir. Zira grup içerisinde her dinî emrin herkes tarafından aynı şekilde benimsenmesi ve eksiksiz bir biçimde yerine getirilmesi orada tek tip bir dindarlık ve insan modelini gündeme getirecektir.

\subsection{Aklın Dinî Konuları Kavrayamayacağı $\rightarrow$ Dogmatizm $\rightarrow$ Fanatizm $\rightarrow$ Araçsal Akıl $\rightarrow$ İdeolojik Dinî Meşruiyet $\rightarrow$ Otoriter Dinî Yapılar $\rightarrow$ Çatışma}

Diğer faktörlerin yanı sıra bilişsel ve entelektüel bir süreç olmaksızın imanın sağlıklı bir şekilde tam manasıyla gerçekleşmesi mümkün görünmemektedir. Bu açıdan

14 DAiş ve Taliban'ın din anlayışlarının ve mensuplarının Selefî ve fundamentalist temellere sahip olduğuna dair bk. Sema Baş, Türkiye'den DAiş'e Katılanlar ve Sempatizanları Üzerine Bir Araştırma (İstanbul: Marmara Üniversitesi, Sosyal Bilimler Üniversitesi, Yüksek Lisans Tezi, 2019); Akbarshah Ahmadi, Dini Tarihi ve Sosyolojik Boyutuyla Taliban Hareketi (Konya: Selçuk Üniversitesi, Sosyal Bilimler Üniversitesi, Yüksek Lisans Tezi, 2011).

15 bk. Laurance Iannaccone, "Why Strict Churches Are Strong”, American Journal of Sociology 99/5 (1994), 1180-1211. 
rasyonel/sorgulayıcı bir şekilde temellendirilen imanın ortaya çıkardığı toplumsal yansımalar dogmatik olmayacağı için orada dinî baskılar gündeme gelmeyecek ve kapalı bir toplum yapılanması görülmeyecektir. Bu noktada bireysel ve sosyal yapıda gün yüzüne çıkan dogmatik eğilimlerin bu temellendirmenin olmadığı durumlarda artış göstereceğini özellikle vurgulamak gerekir. ${ }^{16}$ Aklı nakle tabi kılarak dinî meseleleri ele alan Selefî yaklaşım ise, insan aklının hiçbir zaman tek başına doğruları bulamayacağını savunarak aklı çoğu zaman geri planda bırakmakta, aklın yalnızca dinin yönlendirmesi çerçevesinde hareket etmesini kabul etmektedir. Böyle bir yaklaşım, felsefi eleştirel düşüncenin dine yönelik sorgulamalarını dinî inançları zedeleyen bir tavır olarak görerek onların dışarıdan bir bakışla incelenmesine karşı durmaktadır. Bu yönüyle Selefî tavrın en önemli yönlerinden biri, onun sahip olduğu inançları herhangi bir tartışmaya açmadan ve bütün eleştirileri göz ardı ederek tam bir teslimiyetle ve körü körüne bir bağlllıkla fanatik bir tutum sergilemesidir. ${ }^{17}$ Bundan dolayı kişinin inançlarına sorgulamadan bağlanmasına neden olan fundamentalist eğilimlerden uzaklaşmasını sağlayacak en dikkat çeken unsurlardan birinin entelektüel bilişsel süreç olduğunu özellikle vurgulamak gerekir. ${ }^{18}$

Nas merkezli bir bakış üzerinden hayatı anlamak ve düzenlemek isteyen Selefî tutum, nasların sanki tek bir anlaşılma biçimi varmış gibi hareket ederek işin esası kendi kültürel ve siyasal bakış açılarını naslar üzerinden değerlendirmekte, böylece kendi kişisel ve sosyal yapılarını naslar üzerinden inşa etmeye çalışmaktadır. Buradan da anlaşılacağı üzere nasları kendi hegemonyasını sağlamak üzere araçsallaştıran Selefî tutum, bu yaklaşımıyla kendi inşa ettiği düşünce yapılarının dışında kalan ve farklı yorum biçimleri geliştiren kişi ve grupları ötekileștirerek onlarla din merkezli bir çatışma içerisine girmektedir. ${ }^{19} \mathrm{Bu}$ durumun sonucunda insanı ilerilere taşıyacak ve geliştirecek olan akıl, sadece belli grupların sahip olabileceği ve başkalarının kullanmasına izin verilmeyen bir pozisyonla özdeşleştirilmektedir.

Özellikle aklın araçsal bir yöntemle sadece mevcut dinî inançları tasdik eden bir yaklaşımla işlev görmesi, işin esası kişi ve grupların yalnızca var olan kültürel yapıyla sıkı bir şekilde bağlanmasına yol açmaktadır. Bu açıdan dışarıdan bir bakışla hakikatin sorgulanmak istenmemesi, özellikle muhafazakâr bir tutumun önünü açmaktadır. Bu durum inançların olduğu gibi kabul edilmesi sonucunu doğurarak bireyleri bağnaz bir yaklaşımla kendi dinî yaklaşımları içerisine hapsetmektedir. Bu tavır hem iletişimi ortadan kaldırmakta hem de bu inançların başkalarına dayatılmasına neden

16 Yeşilyurt, “İslam İmanı Fundamentalizmi Destekler mi?”, 769.

17 Beyazyüz - Alkan - Göka, “Fundamentalizmin Psikolojisi”, 361-362.

18 Raoul J. Adam, "Relating Faith Development and Religious Styles: Reflections in Light of Apostasy from Religious Fundamentalism", Archive for the Psychology of Religion 30 (2008), 215-219.

19 Söz konusu fundamentalist tavrın yol açtı̆̆ı sorunları maddeler halinde göstermesi açısından bk. Vamık D. Volkan, Körü Körüne İnanç / Kriz ve Terör Dönemlerinde Geniş Gruplar ve Liderleri (İstanbul: Asi Kitap, 2017), 179. Selefî yaklaşıma dair örnekler için bk. Mehmet Zeki İşcan, "Selefî Akımların İslâm Algısında Zâhirî-Lafzî Yorumun Yansımaları", Zâhirî ve Selefí Din Yorumu, ed. Sönmez Kutlu (İstanbul: Kuramer, 2019), 125-144; Selefîliğin önde gelen isimlerinin bir yandan te'vile karşı çıkarken diğer yandan te'vil yaptıklarını gösteren örnekler için bk. Kubat, "Selefî Perspektifin Tarihselliği", 246-247. 
olmaktadır. Dolayısıyla bu kişiler için hakikat olarak kabul edilen şeylerin bir gerçeklik taşıyıp taşımadığı meselesi herhangi bir anlam ifade etmemektedir. Aynı zamanda kabul edilen inançların bireysel ve sosyal açıdan faydalı olup olmadığının dikkate alınmaması toplumsal açıdan oldukça zarar verici bir mahiyet arz edebilmektedir.

\subsection{Kur'an'ın Mahlûk Olmaması $\rightarrow$ Değişimin Dikkate Alınmaması $\rightarrow$ Dinî Hü- kümlerin Modern Hayatla Uyuşmaması $\rightarrow$ Parçalanmışlık $\rightarrow$ Dinin Sadece Sosyal Yönüne Odaklanılması $\rightarrow$ Dinden Uzaklaşma}

Kur'an'ın mahlûk olmadığı söyleminden hareketle onun nüzulünün tarihsel boyutunu arka plana atan Selefî tutum, insan hayatının realiteyle doğrudan ilişkisini göz ardı ederek psiko-sosyal değişimleri dikkate almamaktadır. Zira Selefî yaklaşımda, İslâm şeriatı olarak ifade edilen dinî hükümler Peygamber döneminde nasıl gerçekleştirildiyse günümüzde de aynı şekilde uygulanması gerekmektedir. $\mathrm{Bu}$ çerçevede özellikle kısas, el kesme cezası, kadının erkeğe kıyasla yarı miras hakkı ve şahitliği, bekâr ve evlilere yönelik kırbaçlama ve recm cezası gibi Kur'an'da yer alan ve Peygamber'in/ashabın uygulamış olduğu cezalar ile geçmiş dönemde İslâm'ın temel hüküm ve ilkelerinden hareketle inşa edilen mezheplere ait fikhî hükümler modern dünyada da uygulanması gereken hükümler olarak kabul edilmektedir. Fakat bu hükümlerin toplumsal ve zamansal değişimi dikkate alınmaksızın her toplumda evrensel bir nitelik arz ettiği söyleminden hareketle uygulanmak istenmesi, modern dönem yaşam şartları ve hukukuyla uyumluluk arz etmemesinden kaynaklanan psiko-sosyal açıdan olumsuz sonuçlar üretmektedir. Bu noktada bu tavrın öne çıkan önemli yönlerinden birisinin, dinin bireysel bir olgu olarak görülmesinden daha ziyade onun sosyal yönünün öne çıarılması olduğunu vurgulamak gerekir. Selefî yaklaşımda bireysel açıdan kişilerin dinî anlayış ve yaşayışları bu toplumsal hükümler üzerinden inşa edildiği için bu hükümler uygulanmaksızın İslâmî yaşayışın mümkün olamayacağı gibi bir söylemle karşılaşılmaktadır. Bu durum ise bireysel dindarlığın geri plana atılarak dinin sadece sosyal yönüne odaklanılmasına neden olmakta ve dinin içsel bir olgu olarak görülmesini engellemektedir. Nitekim Selefî gruplarda yoğun bir şekilde gözlemlenen önemli olgulardan birisi, dinin bireysel bir mesele olmaktan daha ziyade onun sosyal yönünün öne çıkarılmasıdır. Bundan dolayı dinî hükümlerin toplumda uygulanmasını sağlayacak İslâmî yasaların toplumda hâkim olmasını hedefleyen pratiklerin gizli veya açık biçimde ya söylem olarak ya da eylemsel düzeyde yürütüldüğü görülmektedir. Tabii bu yaklaşım toplum içerisinde mevcut devlet yasalarıyla ve yaşam tarzlarıyla bir çatışmayı ortaya çıkarmaktadır. Bu durumda kişinin hem bireysel olarak dinine tam anlamıyla adapte olamaması hem de içinde yaşadığı toplumla bütünleşememesi gibi bir parçalanmışlı̆̆ gündeme getirmektedir. Söz konusu bu parçalanmışlık bireyin kendisine ve toplumuna yabancılaşması sonucunu doğururken, inancın olumlu etkileriyle bütünleşilemediği için gün yüzüne çıkan huzursuzluk kişinin dininden uzaklaşmasına yol açabilmektedir. 


\subsection{Dinî Metinler Üzerinden Hayatı İnşa Etme $\rightarrow$ Hikmet/Insan Eksenli Dinle Bu- luşamama $\rightarrow$ İdeolojik Din İnşası}

Kur'an'ın iniş sürecinde vahyin hayata ve insana dokunan bir yön ihtiva etmesi açısından onun aktüel bir özelliğe sahip olduğu görülmektedir. Ancak vahyin iki kapak arasında girmesinden sonra Kur'an'ın hayatla bütünleşmiş yönü arka plana atılarak ayetler incelenen bir metin olarak ele alınmaya başlanmıştır. ${ }^{20}$ Aynı zamanda ehl-i hadîsin tarihi bağlamdan kopuk rivayet/metin merkezli din anlayışı da Peygamber'in Kur'an'la/hayatla bütünleşmiş yönünü göz ardı etmektedir. Ayrıca dinî metilerin anlaşılmasında akli değerlendirmelerin çoğu zaman dışarıda bırakılması, kişilerin doğru bir şekilde ilahi vahiyle buluşmasının önüne geçmektedir. Bu durum hikmet eksenli, insanın öncelendiği ve evrensel nitelikli düşünme biçimlerinin geliştirilmesini sağlayacak bakış açısının yitirilmesine neden olmaktadır. Nihayetinde ayet ve hadislerin hayatla ilişkisini göz ardı eden Selefî tutum, vahyi ve Peygamber'i hayatla birlikte anlaşılması, yaşanması ve örnek alınması gereken bir olgu olarak görmekten daha ziyade onları hem hayattan bağımsız biçimde anlamaya koyulmakta hem de kendi dünya görüşlerini onaylatmak için bir başvuru kaynağı hâline getirmektedir. Dolayısıyla hayatın tüm yönleriyle bütünleşmiş bir şekilde kendisini göstermesi gereken din, ilk önce kişilerin zihinlerinde inşa olunmakta daha sonra ideolojik bir mahiyete bürünerek hayatla bağını gerçeklikten uzak bir konuma taşımaktadır. Örneğin, İslâm'ın tevhid ilkesi, hayatın bütüncül bir şekilde yaşanılmasını sağlayan ve tüm Müslümanları birleştiren bir muhtevaya sahip olmasına rağmen tekfirci Selefî yaklaşımda tevhidin içeriği ideolojik siyasi bir anlam üzerinden inşa edilerek ayrıştırıcı bir tavırla çatışmaları ortaya çıkarmakta, sonuçta tevhidin birleştirici yönü tam tersi bir yorumla buluşturulmaktadır. Ayrıca metin odaklı bir din anlayışı temel alındığı için dinin kültürel uygulanma biçimleri bütünüyle bid'at olarak değerlendirilerek toplumsal bütünleşmede oldukça önemli bir yere sahip olan geleneksel halk dindarlığı bir çatışma unsuru olarak görülmektedir. ${ }^{21}$

\subsection{Asr-1 Saâdet Dönemiyle Sınırlı Kalma $\rightarrow$ 7. yy. Arap Toplumuyla Özdeşleşme $\rightarrow$ Yerel/Kültürel Unsurlardan Arınma $\rightarrow$ Yabancılaşma}

Selefî söylem, İslâm dinini bütünüyle sadece 7. yüzyıla ve onunla birlikte özdeşleşen ilk dönem İslâm toplumlarında somutlaşan Arap kültürüne has kılmaktadır. Dolayısıyla bu tür bir yaklaşımda İslâm'ın en iyi yaşandı̆̆ı dönem, sadece örneklik teşkil eden ilk dönem İslâm toplumu olmaktadır. Bu sebeple Müslüman toplumlar İslâm'ı en iyi şekilde yaşamak istiyorlarsa 'Asr-1 saâdet' olarak isimlendirilen bu altın çağa yönelmeli, o dönemden sonra ortaya çıkan bozulmuşluklardan uzaklaşmalı, saflaşarak Peygamber'in yaşadığı dinî hayatı kendisine rehber edinmelidirler. Bu söylem irdelendiğinde, burada yerel ve kültürel unsurların dışarıda bırakıldığı, zamanın değişimine bağlı olarak meydana gelen değişikliklerin hep geçmiş üzerinden değerlendirildiği görülmektedir. Bu doğrultuda İslâm’ı yorumlayan Selefî yaklaşım-

20 Öztürk, “Zâhirî-Literalist Anlayışın...”, 298-299.

21 bk. Halil Aydınalp, “Bir Karşıt Kültür Unsuru Olarak Türkiye'de Çağdaş Tekfircilerin Dini Hayata Bakışı ve Anlamları”, Toplum Bilimleri 7/14 (2013), 30-38. 
lar, İslâm'n tek bir evrensel hakikatinin olduğunu iddia etmektedirler. Fakat bu bakış açısında dikkat çeken en önemli husus, İslâm'ın zaman içinde kendisini geliştirerek toplumlara, kültürlere adapte olmasının ve çağlara ait sorunlara yeni çözümler üretmesinin göz ardı edilmesidir. Selefî düşüncenin muhafazakâr bir tutum takınarak özellikle Arap kültürüyle iç içe girmiş din anlayışını savunduğunu, buna mukabil mevâlînin re'yci bir yaklaşımla felsefe, kelâm ve tasavvuf üzerinden kendi kültürü ve eski inanışlarıyla birlikte dine yaklaşımını ciddi şekilde eleştiriye tabi tuttuğunu görmekteyiz. ${ }^{22}$ Dolayısıyla Selefî yaklaşım İslâm'ın farklı kültürlerle temasını hep İslâm'ın Arabi yönünü dikkate alarak değerlendirmekte; bu nedenle diğer kültürlerin İslâm'a yönelik yaklaşımlarını dini tahrif edici bir durum olarak kabul etmektedir. Bu tavır, bireylerin içindeki bulundukları ve yaşadıkları kültürle ideal olarak sunulan toplumsal yapılanma arasında ciddi bir karşıtlık üreterek bireylerin kendi toplumlarına yabancılaşmalarına yol açmaktadır.

\subsection{Dilin Kutsanması $\rightarrow$ Dinin Yerel Üzerinden Evrenselleşememesi $\rightarrow$ Dinin Rasyonel Yönünün Arka Plana Atılması $\rightarrow$ Sağlıksız Dinî Formlar}

Selefî yaklaşım "Dil, varlğın evidir." sözünün ima ettiği anlamı görmezden gelerek dine ait birçok unsuru sadece Arap dili üzerinden inşa etmektedir. Bu durum aslında İslâm'ın varlığını sadece Arap toplumuyla özdeşleştirmekte, dolayısıyla değişen zamanın ve toplumun ruhuna uygun insanın kavrayacağı şekilde İslâmî bir yenilik getirememekte, canlllık üretememektedir. Dinî konuların her toplumun kendi anlam dünyasından damıtılarak inşa olunan kavramlarla anlatılmaması ve o dile bağlı sembol/metaforlarla bütünleştirilmemesi sebebiyle İslâm'ın yerel bir anlayış ve form üzerinden yeniden hayat bulması mümkün olmamaktadır. Bu durumda dinin sabit bir formu -ki onun da hayatın olağan değişimine bağlı olarak ortaya çıkan sosyokültürel gelişimden uzak biçimde sadece ilim dünyasından hareketle inşa olunan bir dil üretimi olduğunu söyleyebiliriz- farklı toplum ve zamanlara aynen aktarılarak İslâm'ın yerel/kültürel tezahürleri dışarıda bırakılmaktadır. Sonuçta bu formla birlikte İslâm'ın yerel bir anlayış üzerinden evrensel yönü kendisini açığa çıkaramamaktadır. Bu durumun en olumsuz yansıması, dinin farklı bir dil evreniyle buluşması neticesinde 'dinin dil ile özdeşleştirilmesine' bağlı olarak dinî ritüellerin gerçekleștirilmesinde sadece ritüalistik formun ve/ya dinin duygu boyutunun öne çıarılarak rasyonel bir şekilde anlaşılamayan ve temellendirilemeyen bir etkinin karşımıza çıkmasıdır. Bu durum ise dinin asıl mesajının arka plana atılarak dinin doğru bir yaklaşımla anlaşılması ve yaşanmasına katkı sağlamayan ritüellerle bütünleşilmesi sonucunu doğurmaktadır.

\subsection{Tarih ve Geleneğe Karşı Duruş $\rightarrow$ Felsefe ve Kültür Karşıtllğı $\rightarrow$ Kültürel Ça- tışmalar}

Selefî ideolojinin tarih ve geleneğe radikal biçimde reddi mirasçı bir tutumla yaklaşması, kültürel ve sanatsal birçok eserin anlamsızlaşmasına ve felsefi bilgisel biri-

22 Evkuran, “Bir Kriz Teolojisi...", 74-75. 
kimin yok sayılmasına neden olmaktadır. Ayrıca Selefîliğin 'saf din' algısı, her türlü kültürel yorumu ve çeşitliliği reddettiği için ortaya çıkan bu kültür karşıtlığ ${ }^{23}$ toplumsal açıdan gelişmiş bir yapının gün yüzüne çıkmasını engellemekte ve sosyal çatışmalara zemin hazırlamaktadır. Aynı şekilde modern Selefî grupların ilk dönem İslâm toplumundan hareketle inşa ettikleri İslâmî yapılanma biçimini ideal bir yapı olarak görmesi ${ }^{24}$ ve bu yapılanmayı özellikle Batı'ya karşı konumlandırması çok ciddi bir kutuplaşmayı karşımıza çıkarmaktadır. Bu durum Batı'nın siyasi ve kültürel hegemonyasına karşı bazı yönlerden doğru ve yararlı tavır ve uygulamaları ortaya çıkarmış olsa bile çoğu zaman ona dair her ne varsa reddedilmesine yol açarak Müslümanları sadece kendi kültürlerine hapseden, insanlığın her türlü evrensel birikiminin dışarıda bırakıldığı içe kapanmış/daraltılmış bir alanda hareket etmelerine neden olan bir anlayışla buluşmaları sonucunu doğurmaktadır.

\subsection{Post/Modern Sorunlara Geçmiş Üzerinden Çözüm Arama $\rightarrow$ Anakronizm $\rightarrow$ Tepkisel Tavır $\rightarrow$ Realiteden Kopuş $\rightarrow$ Kötümser Yaklaşım}

Sosyal ve siyasi baskılar/despotizm, devlet yönetimindeki yozlaşma, ekonomik yoksunluk/eşitsizlikler, hegemonik yönlendirmeler, toplumsal krizler gibi bireylerin hayatını doğrudan etkileyen faktörler ile Batı dünyasıyla özdeşleşen sömürgeciliğin siyasi uzanımları ve modernleşme-küreselleşme sonucunda ortaya çıkan hızlı sekülerlik biçimleri gibi makro düzeyde karşılaşılan problemler Müslümanları çeşitli çözüm arayışlarına yönlendirmektedir. ${ }^{25}$ Bu çerçevede Selefî yaklaşım, Müslümanların içinde bulundukları büyük sorunların kaynağını modern dünyanın bizzat kendisinde görmekte ve çözümü de geçmişe dönerek düzeltebileceğini iddia etmektedir. Geçmişi günümüze taşıyarak huzura kavuşacağını savunan Selefî söylemin bu noktada iki temel hata üzerinde bulunduğu görülmektedir: Birincisi, Müslümanların geri kalmışlı̆̆ını ahlâk, adalet ve gelişmişlik üzerinden değil de dinî emirler üzerinden anlamaya çalışmaktır. Bu yaklaşım günümüz dünyasını ve içinde yaşanılan sosyal yapıyı okuma başarısını gösteremediği için çözümün de yanlış bir yerde aranmasına yol açmaktadır. İkincisi, geçmişi günümüz üzerinden okuyan anakronik bir bakışla meselelere yaklaşmaktır. Anakronik yaklaşım çerçevesinde meselelere odaklanan Selefî tutum, toplumların kendi içindeki tarihsel konumlarını dikkate almadığı için getirilen çözüm önerileri de çağın gerçekleriyle uyuşmayan çözüm arayışlarını gündeme getirmektedir. Aynı zamanda bu durum, düzeltilemeyen birçok sorunun var olduğunu ima ederek hayata umutla bakılmasını engelleyen bir bakış açısını karşımıza çıkarmaktadır. Bu yaklaşımın her yönden çok ciddi psiko-sosyal olumsuz sonuçlar doğurması kaçınılmazdır. Nihayetinde kişiler içinde bulundukları bu durumdan kurtulmak ve onu düzeltmek için tepkisel bir yaklaşımla hem psikolojik olarak normal dışı bir karaktere bürünebilmekte hem de sosyal-siyasal açıdan radikal-militan tutumlara yönelebilmektedir. Bu durumun en kaçınılmaz sonucu, öncelikle küresel

23 Evkuran, "Bir Kriz Teolojisi...”, 75, 81.

24 İşcan, "Tarih Boyunca Selefî Söylem”, 7.

25 Hasanov, "Dinî Fundamentalizmi Ayakta Tutan Temel Faktörler”, 241-258. 
ve yerel yönetimlere karşı ideolojik temelli bir din anlayışı üzerinden siyasal bir duruş sergilenmesi daha sonra mevcut yapının içerisinde alternatif bir yaşam biçiminin inşa edilmeye çalışılmasıdır.

Örneğin, Müslümanları intihar eylemlerine sürükleyen en önemli faktörler arasinda, sosyal ve siyasal dinamiklerin baskısı altında kalan bireylerin bu duruma bir tepki olarak toplumsal gerçeklikten uzak seçmeci bir tavırla literalist bir yaklaşım üzerinden kendilerine dinsel bir meşruiyet aramaları ve böylece inşa edilen dinî idealizm üzerinden güdülenmeleri yer almaktadır. Ayrıca nihai kurtuluşun cennette olacağı söyleminin bu noktada kişilerin eylemlerini motive eden en önemli etkenler arasında yer alması, ${ }^{26}$ dünyadan çok ahiretin öncelenmesi konusunun ne kadar ehemmiyet arz ettiğini bizlere göstermektedir. Ahiretin öne çıkarılıp dünyanın değersizleştirilmesi, bu dünyanın inananlar tarafından imar edilmesi düşüncesini arka plana atarak yaşanılan hayatın önemini geri plana itmektedir. Tabii bu durum ahiretin öncelenmesi sebebiyle hakkıyla bu dünyada var olunamamasına ve varlık gösterilememesine neden olmaktadır. Bu açıdan dinî inançların/metinlerin sosyal ve siyasal etkenler tarafından yönlendirilmesi hususu göz önünde bulundurulduğunda, Selefî grupların oluşmasına yol açan sosyal etkenlerin onların dine yaklaşımlarını belirleyen temel bir niteliğe sahip olduğu anlaşılmaktadır.

\subsection{Bid'at Karşıtlığ $1 \rightarrow$ Muhafazakâr Tutum $\rightarrow$ Konjonktürel Yapının Korunması $\rightarrow$ Dinî Gruplar Arası Çatışma}

Bid'atların reddi, dinin safiyetini koruma gibi bir endişe üzerinden gün yüzüne çıkmış olsa da bu durum inşa edilmiş geleneksel dinî yaşam tarzlarının muhafaza edilmesi gibi bir sonucu da doğurmaktadır. Aynı şekilde Kur'an ve Sünnet'in dışında bir bilgisel kaynağın reddedilerek Selefî imam/liderlerin kendi görüşlerini bu iki kaynak üzerinden inşa etmeleri de hakikat tekelciliğini ortaya çıararak İslâm'nn bu kişilerin kapalı grup anlayışları ve yapılanmalarıyla özdeşleştirilmesi gibi bir durumu karşımıza çıkarmaktadır. ${ }^{27}$ Bu noktada hem inanç hem dinî yapı üzerinde sınırların net bir şekilde çizilmesi, bir yandan inançların zedelenmesini engellemekte diğer yandan mevcut dinî yapının sağlamlaştırılmasını sağlamaktadır. Bunun sonucu olarak grup içi bütünleşme tam anlamıla inşa edilebilmektedir. Dolayısıyla burada dinin temel kaynaklarına dayanma ya da onları koruma duyarlılığının arka planında mevcut toplumsal yapının mahafazası gibi çok önemli bir sosyolojik etkenin var olduğu görülmektedir. Bu durum insanlara din olarak benimsetilmeye çalışılan konuların aslında onları manipüle etme gibi bir araca dönüşebileceğini göstermesi sebebiyle inananların sağlıklı bir dinî anlayışla bütünleşmelerini ciddi şekilde sorunlu hâle getirmektedir. Aynı zamanda hem dini koruma adına gerçekleştirilen bid'at karşıtlığı üzerinden gruplar kendilerinde diğerlerine yönelik bir saldırı hakkı görmekte hem de kapalı grup anlayışının ürettiği karşıtlık

26 Halil Aydınalp, “İntihar Eylemlerinde Dinin Anlamı ve Sınırları”, M.Ü. İlahiyat Fakültesi Dergisi 37/2 (2009), 129-146.

27 İşcan, "Tarih Boyunca Selefî Söylem”, 7. 
duyguları Müslüman birey ve grupların birbirleriyle mücadelelerine yol açmaktadır. Bu tutumlar neticesinde toplumsal bütünleşme bu durumdan ciddi anlamda zarar görmektedir. Hatta Müslümanların birlik oluşturarak güçlü bir yapı oluşturmaları gerekirken, söz konusu yaklaşım onların birbirleriyle daha fazla çatışma içerisine girmelerine neden olmaktadır. ${ }^{28}$

\subsection{Tek Hakikatçi Söylem $\rightarrow$ Fırka-i Nâciye Yaklaşımı $\rightarrow$ Dinî/Grupsal Tekelcilik $\rightarrow$ Karşıtlık $\rightarrow$ Çatışma $\rightarrow$ Araçsallaştırılan Grup Bağlllı̆̆}

Selefî düşüncede yoğun şekilde tek hakikatçi bir söylemin izlerini görmek mümkündür. Burada her şeyi siyah/beyaz olarak algılayan ve kendisiyle diğerlerini dışlayıcı bir yaklaşımla keskin bir şekilde ayıran fundamentalist bir tavır karşımıza çıkmaktadır. Bu noktada dikkat çeken husus, temel inanç konularındaki benzerliklerin göz ardı edilerek onların dışındaki küçük farklılıkların abartılması ve buradan hareketle grupların kendilerini inşa etmesidir. ${ }^{29}$ Bu açıdan birçok dinî grup kendilerini diğerlerinden ayıran inançlarını öne çıkararak ve çoğu zaman kendilerini fırka-i nâciye olarak görerek öteki grupların yanlış bir dinî yaklaşım ve yapılanma üzere olduklarını kabul etmektedirler. Dinî partikülarizm olarak da ifade edilebilecek dinî tekelcilik, hakikatin sadece belli bir gruba ait olduğu düşüncesinden hareketle inşa olunmaktadır. Bu partikülarist anlayışın en önemli yönünün onun karşıtlık üzerine kurulması olduğu söylenebilir. Bu durum gruplar arası kutuplaşmalara yol açarak çatışmaları körüklemektedir. Dinî tekelciliğin en ciddi olumsuz sonuçlarını hoşgörüsüzlükten kaynaklanan tutumların zaman içerisinde fanatizme dönüşmesinde ve daha sonra hayatın sadece belli bir perspektifle alg1lanması neticesinde kendi dışında var olan bir hayatın anlamsız olarak kabul edilmesinde görebiliriz. Bu durum, absolütist karakterli dinlerin partikülarist din anlayışlarında ve kapalı grup yapılarından kaynaklanan bağlılıklarda yoğun bir şekilde gözlemlenmektedir. Karşıtlık düşüncesinin çatışmalara sebebiyet veren temel bir tutum olması, hakikat tekelciliğini aslında oldukça tehlikeli bir silaha dönüştürmektedir. ${ }^{30}$ Ayrıca meydana gelen çatışmalar büyük-grup kimliğinin görünmeyen tarafını gün yüzüne çıkararak hem grup yapısını sağlamlaştırma işlevi görmekte hem de müntesiplerin grupları için büyük fedakârlıklar yapmalarını sağlamaktadır. Bu durum inşa edilen bağlılığın araçsallaştıılmasını dolayısılla grup üyelerinin çeşitli amaçlar için kullanılmaları gibi çok ciddi bir sonucu ortaya çıkarabilecektir. ${ }^{31}$

${ }^{28}$ Örneğin çoğu Selefî düşünceye sahip olan Britanya'daki İslâmî grup ve akımların birbirlerine dışlayıcı bir tutumla yaklaşmaları ve bu nedenle ülkede birlik oluşturamamaları hakkında bk. Aydın Bayram, “Büyük Britanya'daki İslâmî Akımlar”, İslam Medeniyeti Araștırmaları Dergisi 1/3 (2015), 410.

${ }^{29}$ bk. Frank Summers, "Fundamentalism, Psychoanalysis and Psychoanalytic Theories", Psychoanalytic Review 93/2 (2006), 329-352.

30 Kirman, "Hakikat Tekelciliği ve Dinî Partikülarizm", 332-334.

31 bk. Vamı Volkan, "Large-Group-Psychology in Its Own Right: Large-Group Identity and Peacemaking", International Journal of Applied Psychoanalytic Studies 10/3 (2013), 210-246. 
Herkesi sevgiyle kuşatan bir dil kullanımı tüm insanları kapsayan bir dinî perspektif geliştirilmesini mümkün kılmaktadır. Ancak Selefî ve tek hakikatçi söylemler daha çok sevgiyi kendi tekellerine alacak şekilde bir tutum inşa ettikleri için buradan evrensel bir sevgi ve hoşgörünün neşet etmesi mümkün görünmemektedir. Burada 'insanı sevmek' yerine sadece kendi inanç mensuplarının ya da ideolojilerin sevilmesine öncelik verilmesi, herkese sevgiyle yaklaşılmasını önleyerek toplumsal açıdan insani ilişkilerin zedelenmesine yol açmaktadır. Zira artık kişiler birbirlerine insan oldukları için değil, inanç ya da ideolojileri için bağlanmaktadırlar. Bu durum dinî grupların tüm inanç mensuplarını ya da tüm ideolojileri kucaklayan çoğulcu bir yapının inşa edilmesine engel olmakta, aynı zamanda gruplar arası çatışmalara kaynak oluşturmaktadır. Ayrıca dinin doğru anlaşılması için dinin ana kaynaklarına dönerek ve Peygamber'in ve ashabın örnek uygulamalarından hareketle çağdaş dünyaya projeksiyon sunabilecek ilmi araştırmaların Selefî düşüncenin bu özelliklerinden dolayı olumsuz bir yaklaşımla değerlendirilmesi gündeme gelmektedir. Artık geçmiş/gelenek üzerinden dinî hayatın İslâmî temeller üzerinden yeniden inşasını sağlamak amacıyla gerçekleștirilen araştırmalar özellikle Selefî gruplarda gözlemlenen bu olumsuz özellikler sebebiyle insanlara umut vermek yerine onları farklı korkularla karşı karşıya bırakmaktadır.

\subsection{Dinî Bilginin Mutlaklaştırılması $\rightarrow$ İletişimsel Bilginin Reddi $\rightarrow$ Kapalı Grup Yapilanması}

Epistemolojik açıdan bireysel bir yaklaşımla bilginin üretilmesi, insan olmaktan kaynaklanan sebeplerle mutlak bir kesinlik taşımamaktadır. İnsanın bilgi edinmesini etkileyen birçok faktörün var olması, bireysel olarak elde edilen bilgilerin tek başına hakikati yansıtmayacağını anlatmaktadır. Bundan dolayı bilginin kapsayıcı bir biçimde hakikatle buluşabilmesi için bireyler arası bir yaklaşımla ele alınması kaçınımaz bir zorunluluk olarak karşımıza çıkmaktadır. Bir bireyin elde ettiği bilgi, diğer bir kişinin elde ettiği bilgiyle buluşacak ve böylece bilgi daha şümullü bir hâle gelecektir. Bu noktada 'ben ve diğerleri'nin ilişkisi kapsamında ortaya çıkan 'kişiler arası iman gelişimi' olgusu' ${ }^{32}$ göz ardı edilmemelidir. Fakat Selefî gruplar fanatik bir tutumla kendi inanç ve ideolojilerinin dışındaki bilgileri dikkate almadıkları için sadece kendi dar alanları içerisinde bilgiyi ele almakta dolayısıyla kapsamlı bir düşünce inşa edememektedirler. Tabii ki bu durum sosyal yapıyı doğrudan etkileyen bir yön ihtiva ettiği için bilginin üretiminde tüm grupları kapsayan bir yaklaşım sergilenmesinin oldukça önemli bir mesele olduğunu vurgulamak gerekir.

2.15. Kültürel İnşaya Karşı Duruş $\rightarrow$ Dar ve Sı̆̆ Yaklaşım $\rightarrow$ Önyargı $\rightarrow$ İletişimin Kopması $\rightarrow$ Ötekileştirme ve Ayrımcllk $\rightarrow$ İnsanlıktan Uzaklaştırma $\rightarrow$ Baskı ve Şiddet

Kültürün sosyal yapıda var olan diğer yapılarla birlikte inşa edildiğini göz ardı eden hatta buna karşı çıkan Selefî söylemler, dar ve sığ bir tutumla değişimi ve yeni-

32 Sezen, “İman Gelişimi-Dinsel Fundamentalizm İlişkisi”, 204-207. 
liği gündeme getiren yaklaşımları eleştiriye tabi tutmaktadırlar. Bu açıdan Selefî gruplarda gözlemlenen köktencilik, kültürün ve sanatın gelişen yeni yüzlerine karşı çıkarak özgürlük karşıtlığı üzerinden bir tutum takınmaktadır. Bu durum, taassubun öne çıktığı, önyargılı, iletişime ve eleştiriye kapalı tutumlara yol açarken karşılıklı konuşmayı, müzakere ve tartışmayı engellemekte, nihayetinde kültür gelişiminin önüne set çekmektedir. Bunun sebebi katı bir subjektivizmle yorumların mutlaklaştırılması ve kabul edilen kalıplar üzerinden tüm toplumun inşa edilmek istenmesidir. Bunun sonucunda diğer yorumlar kategorik bir genellemeyle ve indirgemeci bir tutumla dişlanmakta, küçümsenmekte, reddedilmekte ve ötekileştirilmektedir. Bu durumun en olumsuz sonucunun ayrıştırıcı bir tavır sergilenerek karşıdaki kişi ve grupların sapkın olarak görülmesi olduğunu vurgulamalıyız. Buna bağlı olarak karşı düşünceye sahip olanlar tekfir edilmekte ve mürted olarak görülmektedir, daha sonra ise insanlıktan uzaklaştırma tutumuyla karşı karşıya bırakılarak baskı ve şiddete maruz birakilmakta hatta öldürülmektedir. ${ }^{33}$

Selefî söylemde herkesi ve her şeyi kuşatan bir din anlayışının var olmadığı görülmektedir. Bütünlükçü bir perspektif geliştirmeyen Selefî düşünce, kuşatıcı ve kapsayıcı söylemlere yalnızca sıcak bakmamakla kalmayıp bu görüşleri savunan yaklaşımları da sert bir şekilde eleştirmekte, bu gruplara yönelik ötekileştirici bir tutum içerisine girebilmektedir. İslâm'ın tevhid ilkesi gereğince hareket etmesi beklenen Müslümanlar tüm inananların birlikte hareket ettiklerinde bir ümmet olacaklarına inanmaktadırlar. Fakat Selefî gruplar bir olmaktan ve bütünleşmekten daha ziyade ayrıștırıcı bir yaklaşımla insanları kendilerinden uzaklaștırmaktadırlar. Dolayısıyla bu üslup ve yöntemlerle birbirleriyle etkileşime giremeyen bireyler birbirlerini tanıyamamakta, sevgiyi inşa edememekte ve bir olamamaktadırlar.

\subsection{Dinî Otoriteleri Kutsallaştırma $\rightarrow$ Kurumsallaşan Dinî Yap1 $\rightarrow$ Dinsel Meşru- iyet $\rightarrow$ Dinî Ortodoksi $\rightarrow$ Bireyselliğin Sonlanması}

Selefî yaklaşımda insan psikolojisinin ve sosyal hayatın sürekli olarak değişen yönü görmezden gelindiği için bireysel ve toplumsal sorunlar, ayrıca evrensel bir pozisyonda değerlendirilen Selef-i sâlihînin söz ve uygulamaları literal bir okumaya tabi tutularak çoğunlukla geçmiş üzerinden çözümler bulunmaya çalışılmaktadır. Tabii bu durum zaman içerisinde değişen insanın geçmiş odaklı yaşamasına ve sosyal yapıdaki büyük değişimlerin de sağlıklı bir şekilde düzenlenememesine neden olmaktadır. Dinî gruplar dinlerin zaman içerisinde kurumsallaşan beşerî yönünü değiştirilmesi mümkün olmayan bir din gibi algilayarak ona kutsallık atfetmektedir. Fakat bu yaklaşım var olan dinî yapıların sorgulanmasının ve eleştirilmesinin önüne geçerek meşruiyetini sadece kendinden alan bir ortodoksi kurmaktadır. Bunun neticesinde var olan dinî yapıların bir düzen ve istikrar taşıdığı iddia edilerek korumacı tutumlarla bireysel düşünüş ve özgür-

33 Kirman, "Hakikat Tekelciliği ve Dinî Partikülarizm”, 334-341; Acar, "Radikal Selefi Zihniyete Bir Reddiye”, 167-171; İslâm tarihindeki örnekler için bk. Mehmet Azimli (ed.), Müslümanların Engizisyonu I / Ölümcül Kovuşturmalar (İstanbul: Mana Yayınları, 2019). 
lüklerin kısıtlandığı görülmektedir. ${ }^{34}$ Ayrıca kendilerini seçmeci ve indirgemeci bir yaklaşımla kurgusal bir geçmiş üzerinden temellendiren ve oradan kendilerini araçsal bir bakışla meşrulaştıran ${ }^{35}$ siyasal yapıların otoritelerinin tahkim edilme işlemi de böylece gerçekleştirilmektedir. Nihayetinde inşa edilen dinî yapıyla bütünleșen inananlar bireysel kimliklerini yitirmeleriyle birlikte kendilerini gruplarıla, liderleriyle ve kutsal metinleriyle özdeşleştirerek grup merkezli yaklaşımla benliklerini inşa etmek zorunda kalmaktadırlar. ${ }^{36}$

\subsection{Tebliğ Misyonu $\rightarrow$ Bireysel Dinî Gelişimin Sekteye Uğraması $\rightarrow$ Kişiler Arası İlişkilerin Bozulması}

Bireyler kendi dinî gelişimlerine odaklanmak yerine başkalarının kusurlarıyla ilgilendikleri için bu durumda şu iki olgunun önemli bir sonuç olarak karşımıza çıkacağını vurgulamak gerekir: Birincisi, kişinin kendisine odaklanmasını sağlayacak içsel sorgulama biçimi daha az etkin hâle getirilecektir. Hatta zamanla kişinin kendisini hakikat olarak görerek olgunlaştığı yönünde bir algılama biçimi görülebilecektir. Zira başkalarına "emir bi'l-marûf nehiy ani'l-münker" yapilırken öncelikle kişinin hem bilgisel hem ahlâkî düzeyde belli bir yetkinliğe sahip olması gerektiği gibi bir izlenim söz konusu olacaktır. İkincisi, başkalarının olumsuz bir bakış üzerinden değerlendirilmesine yol açacak algı biçiminin ortaya çıkmasıdır. Bu durumda insanların hem inanç hem de ahlâkî yönden eksikliklerini aramaya çalışmak kişiler arası sağlıklı iletişimi olumsuz bir şekilde etkileyebilecektir. Örneğin, Selefî bir grup olan Tebliğ Cemaati'nin mensupları, kendilerine ait belirli ilkeler üzerinden insanlara İslâm'ı anlatmak ve onları değiştirmek için diyar diyar gezmeyi kendilerine görev bilirken, ${ }^{37}$ sûfiller ise ilahi aşkın yeryüzündeki tezahürlerini gözleyebilmek, kendilerini olgunlaştırabilmek, dolayısıyla aşk ve cezbelerini artırıp başka insanlara da aşılayabilmek için sık sık seyahat etmişlerdir. ${ }^{38} \mathrm{Bu}$ iki yöntem arasında büyük bir farkl1lık olduğu açıktır.

\subsection{8. Ümmetçilik Anlayışı $\rightarrow$ Tebliğ Faaliyetleri $\rightarrow$ Müslüman Toplumlarda Tek Tip İnanç ve Dinî Yap $\rightarrow$ Müslüman Olmayan Toplumların/Devletlerin İslâmîleşti- rilmesi $\rightarrow$ Çoğulcu Yaklaşımların Sonlanması}

Selefî gruplarda dikkat çeken hususlardan biri, ümmetçilik anlayışının da etkisiyle tebliğ faaliyetlerinin daha çok Müslümanlara yönelik gerçekleștirilmesidir. Burada farklı İslâmî inanışlara sahip olan gruplarla söz konusu farklılıklara rağmen birlik olmak yerine onların aynı inanış ve dinî yapı içerisine dâhil edilmeye çalışılması gibi bir tutumla karşılaşılmaktadır. Dolayısıyla ümmetçilik anlayışının arkasında yer alan

\footnotetext{
Kirman, "Hakikat Tekelciliği ve Dinî Partikülarizm”, 334-335.

Evkuran, "Bir Kriz Teolojisi...", 77-78.

Beyazyüz - Alkan - Göka, "Fundamentalizmin Psikolojisi", 370.

Tebliğ Cemaati'nin temel ilkeleri ve farklı ülkelerdeki geniş yapılanması hakkında bk. Sukron Ma'mun, "Tablighi Jamaat: An Islamic Revivalist Movement and Radicalism Issues", Journal of Islamic and Social Studies 5/2 (2019), 145-159.

38 Ahmet Yaşar Ocak, Türk Sufiliğine Bakışlar (İstanbul: İletişim Yayınları, 1996), 119.
} 
bu olumsuz tutumun ve buna dayalı olarak gerçekleștirilen tebliğin hem bireyler hem de dinî gruplar arasında birleștirici bir yöntemle yapılmamasından kaynaklanan farklı düzeylerde kendisini gösterecek sosyal çatışmalara yol açacağını belirtmek gerekir. Ayrıca farklı din mensuplarına gerçekleştirilen tebliğlerin akli bir delillendirmeden daha ziyade daha çok fideist bir yaklaşımla gerçekleştirilmesi, hem tebliğ edenin amacını başarılı bir şekilde yerine getirememesine hem de karşısındaki kişiyi duygusal bir iknadan hareketle dine davetin baskıcı bir karakter arz etmesine neden olabilecektir. Bu durumda hem iletişim biçiminin anlamsızlaşması hem de zarar görmesi söz konusu olacaktır.

Müslüman olmayan ülkelerde özellikle Batı dünyasında gerçekleştirilen bazı tebliğ faaliyetleri derinlemesine incelendiğinde, burada sadece kişilerin bireysel olarak Müslüman olmasının hedeflenmediği, aynı zamanda ondan daha önemli bir amacın Selefî düşünceye bağlı bir İslâm toplumunun inşası olduğunu özellikle vurgulamak gerekir. Bu tutum, söz konusu ülkelerde tebliğ faaliyetlerinin sorgulanması ve bu faaliyetleri gerçekleştiren kişilerin topluma/devlete karşı iyi niyetli olmadıkları yönünde bir bakışı ortaya çıkarabilmektedir. ${ }^{39}$ Bu noktada vurgulanması gereken en önemli husus, Selefî yaklaşımda bireysel bir din anlayışının tasvip edilmemesi sebebiyle tebliğ faaliyetlerinin topluma/devlete yönelik bir strateji geliştirmek zorunda kalmasıdır. Bu durum toplumsal yapının öncelenmesi nedeniyle bireysel dindarlığın önemsenmemesi ve karşı çıkılmasına yol açmaktadır. Tüm bu tutumlar neticesinde karşımıza çıkan en ciddi sonuç hem Müslümanların hem de farklı inanç mensuplarının aynı toplum içerisinde çoğulcu bir yaklaşımla bir arada var olamamasıdır.

\subsection{Dârülharp Söylemi $\rightarrow$ Radikalizm $\rightarrow$ Şiddete Başvurma $\rightarrow$ Grup İçi/Grup D1- şı İslâmofobi}

Özellikle modern dünyanın seküler siyasal yönetim biçimlerine tepki göstererek ideolojik kavramsallaştırmalar üzerinden kendi metinlerini inşa eden Selefî gruplar, İslâm toplumlarında devlet yönetimini temel bir problem olarak görmektedirler. Buna bağlı olarak öncelikle devlet yapılarını daha sonra tepeden inmeci bir tavırla tüm toplumsal yapıyı köklü bir değişime tabi tutarak onları İslâmîleștirme yolunda çeşitli eylemlere başvurmaktadırlar. "Cahiliye toplumu", "Rabbanî metot", "tevhidî öncü cemaat", "dârülislâm/dârülküfür" ve "cihat" gibi kavramların aşırı yorumlara tabi tutularak ideolojik bir yaklaşım çerçevesinde kullanılması neticesinde âdeta toplumun tümünün tekfirle itham edilmesi, devletle ve halkla karşı karşıya kalınması sonucunu ortaya çıkarmaktadır. Bu kapsamda birbirinden farklı metotlara sahip olan İslâmî gruplar söz konusu olsa da burada özellikle Selefî düşünceden beslenen radikal fundamentalist hareketlerin gerçekleştirdikleri şiddete dayalı eylemler dikkat çekmektedir. ${ }^{40}$ Söz konusu bu eylemler farklı inanışlara sahip olan grupların bir arada yaşa-

39 Susanne Olsson, “Proselytizing Islam - Problematizing “Salafism”, The Muslim World 104 (2014), 193.

40 Söz konusu grupların özellikleri ve faaliyetleriyle ilgili geniş bilgi için bk. Mehmet Ali Büyükkara, “Günümüzde Selefîlik ve İslâmî Hareketlere Olan Etkisi”, Tarihte ve Günümüzde Selefilik, ed. Ahmet Kavas (İstanbul: Çınar Matbaası, 2014), 485-524. 
masını ve birlikte var olmasını engellemektedir. Bu ortamda bırakın farklı dinlerin ve inançların bir arada yaşamasını, birbirinden farklı niteliklere sahip olan Selefî grupların dahi birbirlerinin varlıklarına tahammül ederek ortak bir yapıda bulunması mümkün değildir. Çünkü bu tutumların açığa çıkmasını tetikleyen fanatizm ve özellikle karşıtlık üzerinden inşa olunan radikalizm farklı olanın her zaman dışarıda bırakılması sonucunu doğurmaktadır. Nihayetinde tüm bu tutumlar hem Müslüman toplumlarda bir korkuya yol açmakta hem de dünya genelinde bu gruplar üzerinden İslâmofobinin oluşmasına neden olmaktadır. ${ }^{41}$

\subsection{Ataerkil Dinî Söylem $\rightarrow$ Kadın Üzerinden Sosyal Dinî Hayatın Açılanması $\rightarrow$ Kadına Yönelik Cinsiyetçi Bir Tutum Sergilenmesi $\rightarrow$ Kadının Sosyal Hayattan Geri Plana İtilmesi}

İlk dönem ataerkil toplum yapılanmasının dinî alandaki yansımalarını ${ }^{42}$ kendisine model alan Selefî düşünce, o zamanın özelliklerine bağlı olarak ortaya çıkan sosyal yapılanma biçimini evrensel bir form biçiminde görmekte ve onu günümüz toplumlarında pratik etmeye çalışmaktadır. Tabii ki bu durumda modern hayatın kadının özgürlüğü ve hayatına yönelik birçok yönden genişletici imkânlar sunmasına karşın Selefî düşüncenin kadına biçtiği statü ve rol arasında ciddi bir uyumsuzluk söz konusu olmaktadır. Bu çerçevede özellikle kadının modern hayattaki konumunu dikkate almadan verilen fetvalar, kadının rolü vurgulanarak açıklanmaya çalışılan sekülerleşme yorumları, kadının bir birey olarak kabul edilmesinden daha ziyade ona cinsiyetçi bir tavırla yaklaşılması ve buna bağlı olarak onun sosyal ve dinî hayatını daraltacak şekilde yönlendirmeler yapılması ve çeşitli uygulamalara gidilmesi birçok olumsuz sonucun ortaya çımasına neden olmaktadır. ${ }^{43} \mathrm{Bu}$ durum ise kadın ve erkeğin hep birlikte var olması gereken yaşamda kadının aleyhinde inşa edilen bir sosyal yapıyla karşılaşılmasına yol açmaktadır.

\subsection{Geleneksel Eğitim Yöntemleri $\rightarrow$ Özgürlükçü Eğitim Anlayışının Engellen- mesi $\rightarrow$ Bireyi Grupla Özdeşleştirme}

Eğitim-öğretim müfredat ve yöntemlerini Asr-1 saâdet döneminden ve geleneğe bağlı klasik bir usul üzerinden inşa eden Selefî yaklaşım, modern bir perspektifle bireyi eğitmemekte ve/ya böyle bir metoda karşı çımmaktadır. Özellikle eleştirel ve felsefi yaklaşımdan uzak durması ya da ona karşıt bir söyleme sahip olması sebebiyle, dışardan bir bakışla gerçekleştirilecek özgürlükçü bir eğitimin inanan kişiyi dinden uzaklaştıracağına dair temel bir tavır sergilemektedir. ${ }^{44} \mathrm{Bu}$ tutumun en önemli sonu-

${ }_{41}$ bk. Mevlüt Uyanık, “Dünyada İslamfobia'yı Besleyen Unsur Olarak Neo-Selefi Öğreti 'Bir Zihniyet Analizi"', 21. Yüzyllda Sosyal Bilimler 11 (2015), 319-332.

42 Ayrıntılı bilgi için bk. Hidayet Şefkatli Tuksal, Kadın Karşııtı Söylemin İslam Geleneğindeki İzdüşümleri (Ankara: OTTO Yayınları, 2012).

43 İsmailağa Cemaati'ndeki örnekler için bk. Zehra Işık, Modern Kentte Farkl Kadın Dindarlkları: ístanbul Örneği (İstanbul: Marmara Üniversitesi, Sosyal Bilimler Enstitüsü, Doktora Tezi, 2020), 276-356.

${ }^{44}$ Geleneksel ve modern eğitim-öğretim yöntemlerinin karşılaştırılması, ayrıca hem medreselerdeki hem de geleneksel eğitim anlayışından beslenen tarikat, cemaat ve modern eğitim kurumlarındaki 
$\mathrm{cu}$, bireyin içinde bulunduğu grubun/mezhebin dışına çıkmasını sağlayacak sorgulayıcı bakış açısının engellenmesi neticesinde bireyin kapalı bir grup yapılanması içerisinde kalmasıdır. Nihayetinde birey bu durumda kendisini grupla özdeşleştirmek zorunda kalacaktır. Bundan dolayı Selefî gruplarda gözlenen hem eğitim müfredatında yer alan bilgilerin içeriği hem de öğretim yöntemlerinin ideolojik bir amaç uğruna araçsal hâle getirilmesi, bireyin hegemonik bir sistem içerisinde hareket etmesine ve sahte bir özgürlük üzerinden yönlendirilmesine neden olmaktadır.

\section{Tartışma ve Sonuç}

Her ne kadar Selefî din anlayışlarına bağlı olarak ortaya çıkan tüm psiko-sosyal olumsuz tutumlara dair geniş kapsamlı empirik araştırma verileri söz konusu olmasa da; öncelikle Selefî düşünce ve fundamentalizm üzerine yapılmış araştırmalar dikkate alındığında ayrıca Batı toplumlarında, İslâm dünyasında ve özellikle Türkiye'deki Selefî yaklaşımların mevcut sosyo-kültürel yapısı göz önünde bulundurulduğunda Selefî düşüncenin yol açabileceği olumsuz sonuçların bu toplumlarda yoğun bir şekilde gözlendiğini dolayısıyla bu makalede gösterilen olumsuz etkilerin genel olarak bireylerde ve sosyal yapı içerisinde bir karşılı̆̆ının olduğunu söylemek mümkündür. Dolayısıyla bu din anlayışları benimsendiği sürece söz konusu olumsuz yansımaların kişi, grup ve toplumları genel anlamda etkilemeye devam edeceği söylenebilir. Fakat bu noktada söz konusu din anlayışlarının Selefî düşünceye sahip olan her kişide aynı olumsuz sonuçlara yol açıp açmayacağına dair bir tartışma karşımıza çıkabilir.

$\mathrm{Bu}$ çerçevede konunun sağlıklı bir şekilde aydınlatılabilmesi açısından Selefî düşünceye dair iki özellik üzerinde durmak gerekir. Araştırmada tespit edilen bulgular dikkatli bir şekilde incelendiğinde, iki özellik dışında Selefî din anlayışlarının Müslümanların genel olarak benimsedikleri inanç ögelerinden oluştuğu görülmektedir. Dışarıda kalan unsurlardan birincisi; özellikle radikal, cihatçı ve tekfirci Selefî grupların şiddet üretmesi ve devletle/toplumla çeşitli yönlerden çatışma içerisine girmesidir. İkincisi de tarihi süreç içerisinde inşa edilen dinî kültürel geleneğin Selefî oluşumlar tarafından reddedilmesi sonucunda bu hareketlerin tepki görmesidir. Burada özellikle yerel kültürle iç içe girmiş şekilde bir dinî anlayışa/geleneğe sahip olunmasının ve farklı dinî inanış/pratiklere hoşgörü ile bakabilen bir tavır sergilenmesinin Selefî oluşumları betimlemede en önemli iki unsur olarak karşımıza çıktığını belirtmek gerekir. Fakat bu durum Selefîlik ya da Selefî gruplar ile Müslümanların genel olarak benimsemiş oldukları inançların birbirinden oldukça farklı olduğu şeklinde yanlış bir algıyı ortaya çıkarmaktadır. Dolayısıyla makalede ayrıntılı bir şekilde gös-

yaklaşımların Selefî bir içeriğe ve yönteme sahip olduklarına dair bk. Najwan Saada, “The Theology of Islamic Education from Salafi and Liberal Perspectives”, Religious Education 113/4 (2018), 406-418; Adil Bor, “Geleneksel Medrese Eğitiminin Kur’an Tasavvuru -Tespitler ve Öneriler-“, İslam ve Yorum: Temel Tartışmalar, Imkânlar ve Sorunlar, haz. Fikret Karaman (Malatya: Malatya İlahiyat Vakfı, 2017), 2/293311; M. Hanefi Palabıyık - Zeynep Çelik - Esra Katırc1, "Medrese Eğitimi ve Çağdaş Eğitimde Eğitim Anlayışının Mukayesesi”, Medrese ve İlahiyat Kavşağında İslâmî İlimler (Uluslararası Sempozyum), ed. İsmail Narin (Bingöl: Bingöl Üniversitesi Yayınları, 2013), 2/17-43. 
terildiği üzere, Selefî din anlayışlarının geniş bir kapsama sahip olması nedeniyle bu din anlayışlarına bağlı olarak karşımıza çıkan olumsuz yansımaların sadece Selefilik ve Selefî gruplara ait özellikler olduğunun düşünülmesi doğru bir yaklaşım olarak kabul edilmemelidir. Bu noktada Selefî din anlayışlarının psiko-sosyal açıdan yol açtığı makale içerisindeki maddelerde ayrı ayrı belirtilen her bir olumsuz tutumun Selefî din anlayışlarına sahip olan tüm Müslümanları çeşitli yönlerden olumsuz etkileyeceği söylenebilir. Dolayısıyla Müslümanları her yönden inşa ettiği düşünülen bu din anlayışlarının onların inançlarını ve bireysel/sosyal yaşantılarını geliştirmekten daha ziyade onları çeşitli açılardan olumsuz etkileyebilecek özellikler barındırması, söz konusu unsurların inananlar tarafindan dikkatle incelenmesini zorunlu kılmaktadır.

\section{Kaynakça}

Acar, Mustafa. "Radikal Selefi Zihniyete Bir Reddiye". Muhafazakâr Düşünce 2/6 (2005), 163-196.

Adam, Raoul J. "Relating Faith Development and Religious Styles: Reflections in Light of Apostasy from Religious Fundamentalism”. Archive for the Psychology of Religion 30 (2008), 201-231.

Ahmadi, Akbarshah. Dini Tarihi ve Sosyolojik Boyutuyla Taliban Hareketi. Konya: Selçuk Üniversitesi, Sosyal Bilimler Üniversitesi, Yüksek Lisans Tezi, 2011.

Albayrak, Hafize Şule. Hristiyan Fundamentalizmi. İstanbul: Marmara Üniversitesi, Sosyal Bilimler Enstitüsü, Yüksek Lisans Tezi, 2006.

Ali, Mohamed. "Understanding Salafis, Salafism and Modern Salafism”. İslâmiyyât 41/1 (2019), 125-136.

Altemeyer, Bob - Hunsberger, Bruce. “Authoritarianism, Religious Fundamentalism, Quest and Prejudice". The International Journal for the Psychology of Religion 2/2 (1992), 113-133.

Ay, Mahmut. "Tanrı Tasavvurlarının Politik Tasarımlara Yansıması”. Ankara Üniversitesi İlahiyat Fakültesi Dergisi 46/2 (2005), 107-130.

Aydınalp, Halil. “İntihar Eylemlerinde Dinin Anlamı ve Sınırları”. M.Ü. İlahiyat Fakültesi Dergisi 37/2 (2009), 129-146.

Aydınalp, Halil. “Bir Karşıt Kültür Unsuru Olarak Türkiye'de Çağdaş Tekfircilerin Dini Hayata Bakışı ve Anlamları”. Toplum Bilimleri 7/14 (2013), 27-50.

Azimli, Mehmet (ed.). Müslümanların Engizisyonu I / Ölümcül Kovuşturmalar. İstanbul: Mana Yayınları, 2. Basım, 2019.

Baş, Sema. Türkiye'den DAIŞ̧’e Katılanlar ve Sempatizanları Üzerine Bir Araştırma. İstanbul: Marmara Üniversitesi, Sosyal Bilimler Üniversitesi, Yüksek Lisans Tezi, 2019.

Bayram, Aydın. "Büyük Britanya'daki İslâmî Akımlar”. İslam Medeniyeti Araştırmaları Dergisi 1/3 (2015), 390-415.

Beyazyüz, Murat - Alkan, F. Sevinç Göral - Göka, Erol. “Fundamentalizmin Psikolojisi”. Avrasya Dosyast 13/3 (2007), 355-384.

Büyükkara, Mehmet Ali. "Günümüzde Selefîlik ve İslâmî Hareketlere olan Etkisi”. Tarihte ve Günümüzde Selefilik. ed. Ahmet Kavas. 485-524. İstanbul: Çınar Matbaası, 2014.

Büyükkara, Mehmet Ali. “Türkiye'de Radikal Dini-Siyasal Akımlar”. Demokrasi Platformu (Türkiye'de Tarikatlar ve Cemaatler - III) 2/8 (2006), 107-166.

Bor, Adil. "Geleneksel Medrese Eğitiminin Kur'an Tasavvuru: Tespitler ve Öneriler”. İslam ve Yorum: Temel Tartışmalar, İmkânlar ve Sorunlar. haz. Fikret Karaman. 2/293-311. Malatya: Malatya İlahiyat Vakfi, 2017.

Cesari, Jocelyne. "Ethnicity, Islam, and les Banlieues: Confusing the Issues". SSRC (Kasım 2005), 1-8. http://hia.squarespace.com/storage/Ethnicity\%20Islam\%20and\%20les\%20banlieues\%20\%20Confusing\%20the\%20Issues\%20J.Cesari.pdf Accessed November 2, 2012. 
Çetin, Özer. Rollo May Psikolojisinde Din ve Kişilik. İstanbul: İz Yayıncılık, 2019.

Demir, Habip. “Çağdaş Şiî Islah Düşüncesinde Selefî Etkiler: Şerîat Senglecî Örneği”. Hitit Üniversitesi İlahiyat Fakültesi Dergisi 19/1 (2020), 245-278.

Demirbilek, Mine - Atalay, Hakan. “Türkiye'de Selefilik Araştırmalarında Rastlanan Bazı Sorunlar”. Journal of Islamic Research 29/2 (2018), 448-459.

Demirli, Ekrem. Şair Sûfiler - Mevlana, Yunus ve Niyazi-i Mısrî Üzerine İncelemeler. İstanbul: Sufi Kitap, 2. Basım, 2018.

Evkuran, Mehmet. "Bir Kriz Teolojisi ve Toplumsal Hareket Olarak Selefilik -Selefî İdeoloji ve İslâm Dünyasındaki Etkileri Üzerine Bir Analiz-". Illahiyat Akademi 1/1-2 (2015), 71-90.

Güldü, Özgür. "Sağ Kanat Yetkeciliği Ölçeği: Uyarlama Çalışması". Ankara Üniversitesi Sosyal Bilimler Enstitüsü Dergisi 2/2 (2011), 27-51.

Hasanov, Bahram. "Dinî Fundamentalizmi Ayakta Tutan Temel Faktörler”. AİB̈̈ Sosyal Bilimler Enstitüsü Dergisi 6/3 (2016), 241-258.

Iannaccone, Laurance. "Why Strict Churches Are Strong". American Journal of Sociology 99/5 (1994), 1180-1211.

Işık, Zehra. Modern Kentte Farklı Kadın Dindarlıkları: İstanbul Örneği. İstanbul: Marmara Üniversitesi, Sosyal Bilimler Enstitüsü, Doktora Tezi, 2020.

İşcan, Mehmet Zeki. “Tarih Boyunca Selefî Söylem”. İlahiyat Akademi 1/1-2 (2015), 1-14.

İşcan, Mehmet Zeki. "Selefî Akımların İslâm Algısında Zâhirî-Lafzî Yorumun Yansımaları". Zâhirîve Selefî Din Yorumu. ed. Sönmez Kutlu. 125-144. İstanbul: KURAMER, 2019.

Karaca, Faruk - Hacıkeleşoğlu, Hızır. “Allah Tahayyüleri Ölçeği”. İlted: İlahiyat Tetkikleri Dergisi 54/2 (2020), 67-83.

Kavas, Ahmet. “Avrupa Selefilliği”. Tarihte ve Günümüzde Selefilik. ed. Ahmet Kavas. 615-657. İstanbul: Çınar Matbaası, 2014.

Kazanç, Fethi Kerim. “Eş’arî Kelam Sisteminde Allah Anlayışı ve Doğurduğu Sorunlar”. X. Kelâm Anabilim Dalı Koordinasyon Toplantısı ve Tanrı Tasavvurları ve Sosyal Hayata Yansimalar Sempozyumu. ed. Ramazan Biçer - Süleyman Akkuş. 107-142. Sakarya: Sakarya Üniversitesi İlahiyat Fakültesi Yayınları, 2005.

Kellecioğlu, Özgür. Psikopolitik Yönden İslamcı Fundamentalizmin İncelenmesi. Ankara: Kara Harp Okulu, Savunma Bilimleri Enstitüsü, Yüksek Lisans Tezi, 2007.

Kirman, Mehmet Ali. "Sekülerleşme Perspektifinden Dinî ve Seküler Fundamentalizmler". Uluslararası Sosyal Araştırmalar Dergisi 1/2 (2008), 274-291.

Kirman, Mehmet Ali. "Hakikat Tekelciliği ve Dinî Partikülarizm”. Çukurova Üniversitesi İlahiyat Fakültesi Dergisi 19/2 (2019), 330-346.

Koca, Ferhat. "İslâm Düşünce Tarihinde Selefîlik: Tarihsel Serüveni ve Genel Karakteristiği”. İlahiyat Akademi 1/1-2 (2015), 15-70.

Kubat, Mehmet. "Selefî Perspektifin Tarihselliğii". İslami Araştırmalar Dergisi 17/3 (2004), 235-251.

Laythe, Brian vd. "Religious Fundamentalism as a Predictor of Prejudice: A Two-Component Model". Journal for the Scientific Study of Religion 41/4 (2002), 623-635.

Ma'mun, Sukron. “Tablighi Jamaat: An Islamic Revivalist Movement and Radicalism Issues”. Journal of Islamic and Social Studies 5/2 (2019), 145-159.

Marty, Martin E. - Appleby, R. Scott (ed.). Fundamentalisms Comprehended. Chicago: University of Chicago Press, 1995.

Murken, Sebastian. “Tanrı'yla İlişki ve Ruh Sağlı̆̆ı- Bir Modelin Gelişimi ve Deneysel İncelemesi”. çev. Yusuf Macit. Çukurova Üniversitesi İlahiyat Fakültesi Dergisi 12/2 (2012), 299-316.

Nâfi', Beşîr Mûsâ - Abdu'l-Mevla, İzzuddin - Takıyye, El-Hevvâs (ed.). Arap Dünyasında Selefilik ve Selefi Hareketler. çev. Nurullah Çakmaktaş. İstanbul: Yarın Yayınları, 2016.

Ok, Üzeyir. "Biyografik Anlatıya Dayalı İnanç Gelişimi Biçimleri ve Nicel Ölçümler”. Çukurova Üniversitesi İlahiyat Fakültesi Dergisi 12/2 (2012), 121-155. 
Olsson, Susanne. "Proselytizing Islam - Problematizing ‘Salafism”'. The Muslim World 104 (2014), 171-197.

Ocak, Ahmet Yaşar. Türk Sufiliğine Bakışlar. İstanbul: İletişim Yayınları, 1996.

Ocak, Hasan. "Klasik İslam Düşüncesinde İki Farklı Tanrı Tasavvuru”. Türkiye Din Eğitimi Araşturmaları Dergisi 6 (2018), 125-141.

Öztürk, Mustafa. "Zâhirî-Literalist Anlayışın İslam Düşüncesindeki ve Çağdaş Selefillikteki İzdüşümleri”. Zâhirî ve Selefi Din Yorumu. ed. Sönmez Kutlu. 295-332. İstanbul: Kuramer, 2019.

Palabıyık, M. Hanefi - Çelik, Zeynep - Katırcı, Esra. "Medrese Eğitimi ve Çağdaş Eğitimde Eğitim Anlayışının Mukayesesi". Medrese ve İlahiyat Kavşağında İlâmî İlimler (Uluslararası Sempozyum). ed. İsmail Narin. 2/17-43. Bingöl: Bingöl Üniversitesi Yayınları, 2013.

Saada, Najwan. "The Theology of Islamic Education from Salafi and Liberal Perspectives". Religious Education 113/4 (2018), 406-418.

Sağır, Ayşe Çelik. Türkiye'de Günümüz Dini Köktenciliğinin İdeolojisi: Tevhid Dersleri ve Selefiyye Siteleri Örneği. İstanbul: Marmara Üniversitesi, Sosyal Bilimler Enstitüsü, Yüksek Lisans Tezi, 2013.

Saroglou, Vassilis. "Studying Religion in Personality and Social Psychology". Religion, Personality, and Social Behavior. ed. Vassilis Saroglou. 1-28. New York: Psychology Press, 2014.

Sancar, Faruk. "Selefîlik Bir Mezhep mi Yoksa Bir Düşünme Tarzı mı? Selefi Düşüncenin Şifrelerine Dair Bir Değerlendirme”. Dinbilimleri Akademik Araştırma Dergisi 15/3 (2015), 21-49.

Sezen, Abdulvahid. "İman Gelişimi-Dinsel Fundamentalizm İlişkisi: Üniversite Öğrencileri Örneği”. Dokuz Eylül Üniversitesi İlahiyat Fakültesi Dergisi 28 (2008), 203-232.

Sezen, Abdulvahid. "Dinsel Fundamentalizm Ölçeğinin Türkçe Çevirisinin Geçerlik ve Güvenirlik Çalışması". Sakarya Üniversitesi İlahiyat Fakültesi Dergisi 30 (2010), 135-247.

Subaşı, Necdet. “Fundamentalizm, İslam ve Hayat”. İslam Araştırmaları 8/3-4 (1995), 250-262.

Summers, Frank. "Fundamentalism, Psychoanalysis and Psychoanalytic Theories". Psychoanalytic Review 93/2 (2006), 329-352.

Şahin, Hanifi. "İhya Islah Hareketleri ve Selefîlik İrtibatı". e-makâlât Mezhep Araştırmaları 9/1 (2016), 1-37.

Şener, Nazırhan. Türkiye'de Dinin Selefì İnşası. Ankara: Ankara Üniversitesi, Sosyal Bilimler Enstitüsü, Yüksek Lisans Tezi, 2020.

Tokat, Latif. “Dinin Sembolik Dili”. Milel ve Nihal 6/1 (2009), 75-98.

Uyanık, Mevlüt. "Dünyada İslamfobia'yı Besleyen Unsur Olarak Neo-Selefi Öğreti 'Bir Zihniyet Analizi”'. 21. Yüzyllda Sosyal Bilimler 11 (2015), 319-343.

Volkan, Vamık. "Large-Group-Psychology in Its Own Right: Large-Group Identity and Peacemaking". International Journal of Applied Psychoanalytic Studies 10/3 (2013), 210-246.

Volkan, Vamık D. Körü Körüne İnanç / Kriz ve Terör Dönemlerinde Geniş Gruplar ve Liderleri. İstanbul: Asi Kitap, 2017.

Wiktorowicz, Quintan. “Anatomy of the Salafi Movement". Studies in Conflict and Terrorism 29/3 (2006), 207-239.

Wood, Simon A. - Watt, David Harrington (ed.). Fundamentalism: Perspectives on a Contested History. Columbia, SC: University of South Carolina Press, 2014.

Yeşilyurt, Temel. “İslam İmanı Fundamentalizmi Destekler mi?”. Türkiye’nin Güvenliği Sempozyumu. ed. Orhan Kılıç - Mehmet Çevik. 763-770. Elazığ: Fırat Üniversitesi, 2001.

Tuksal, Hidayet Şefkatli. Kadın Karşıtı Söylemin İslam Geleneğindeki İzdüşümleri. Ankara: OTTO Yayınları, 2012. 